\title{
Fish assemblages at mesophotic depths in the Pacific: A comparison between continental and oceanic islands of Mexico
}

\section{Ensamblajes de peces en la zona mesofótica del Pacífico: Una comparación entre islas continentales y oceánicas de México}

\author{
Manuel F Velasco-Lozano ${ }^{1}$, Georgina Ramírez-Ortiz ${ }^{2}$, Héctor Reyes-Bonilla ${ }^{1}$, \\ Jordan A Hollarsmith ${ }^{3 *}$ \\ ${ }^{1}$ Departamento Académico de Ciencias Marinas y Costeras, Universidad Autónoma de Baja California Sur, \\ Carretera al Sur, km 5.5, CP 23080, La Paz, Baja California Sur, Mexico. \\ ${ }^{2}$ Programa de Ecología Pesquera, Centro de Investigaciones Biológicas del Noroeste, Av. Instituto Politécnico \\ Nacional 195, CP 23096, La Paz, Baja California Sur, Mexico. \\ ${ }^{3}$ Department of Biological Sciences, Simon Fraser University, 8888 University Drive, Burnaby, British \\ Columbia, V5A 1S6, Canada. \\ *Corresponding authors. E-mail: GRO, gramirez@pg.cibnor.mx; JAH, jordan_ann_hollarsmith@sfu.ca
}

\begin{abstract}
Mesophotic ecosystems are found at depths of the ocean defined by the amount of incident light (1\%-10\% of light found at the surface). These ecosystems remain unexplored in many regions, including the Pacific region along the coast of Mexico, given the difficulty of accessing them using traditional methods, such as scuba. Using a remotely operated vehicle, we characterized fish assemblages across rock and sand habitat at mesophotic depths around continental islands in the Gulf of California and oceanic islands in the Revillagigedo Archipelago in Mexico. We conducted 78 video-transect surveys and identified observed fish to the lowest taxonomic level possible. Using species' presence per video-transect, we calculated traditional diversity indices (species richness, taxonomic distinctness, and trophic level) and functional indices (number of functional entities, functional richness, and functional volume) for each island group and habitat type. The model results indicated that habitat type was the most important factor for predicting mesophotic fish diversity. The functional indices showed higher values for the rocky reefs of oceanic islands than for the sandy habitats, driven primarily by the presence of elasmobranchs and commercially important transpacific species. While the values of taxonomic distinctness and functional diversity could indicate that the mesophotic reefs in the oceanic island group are more ecologically intact than those around the continental islands, it will require more exploration to determine if this condition persists over time and if these ecosystems could serve as refuges for commercial fish species against the increasing number of disturbances impacting shallow reefs.
\end{abstract}

Key words: remotely operated vehicles, species richness, functional volume, trophic level, biogeographic provinces.

RESUMEN. Los ecosistemas mesofóticos se encuentran en una capa del océano definida por la cantidad de luz incidente (1\%-10\% con respecto a la superficie). Estos ecosistemas permanecen inexplorados en algunas regiones, como el Pacífico a lo largo de la costa mexicana, debido al difícil acceso mediante métodos tradicionales como el buceo autónomo. Se utilizó un vehículo operado remotamente para caracterizar los ensamblajes de peces de arrecifes rocosos y zonas arenosas en profundidades mesofóticas alrededor de islas continentales del golfo de California e islas oceánicas del archipiélago de Revillagigedo (México). Se realizaron 78 video-transectos y se identificaron los peces observados al mínimo taxón posible. Con base en la presencia de especies por video-transecto, se calcularon índices de diversidad tradicionales (riqueza de especies, diferenciación taxonómica y nivel trófico) e índices funcionales (número de entidades funcionales, riqueza funcional y volumen funcional) para cada conjunto insular y tipo de hábitat. Los modelos aplicados señalaron que el tipo de hábitat es el factor con mayor efecto en la diversidad de peces mesofóticos. Los índices funcionales presentaron mayores valores para los arrecifes rocosos de islas oceánicas que para los hábitats arenosos, lo que se asocia con la presencia de elasmobranquios y especies transpacíficas de importancia comercial. Aunque los valores de diferenciación taxonómica y diversidad funcional podrían indicar que los arrecifes mesofóticos del conjunto oceánico se encuentran en mejor estado de conservación que los del conjunto continental, se requiere mayor exploración para determinar si esta condición perdura en el tiempo y si estos ecosistemas pueden ser un refugio para especies comerciales ante el creciente impacto de disturbios en arrecifes someros.

Palabras clave: vehículos operados remotamente, riqueza de especies, volumen funcional, nivel trófico, provincias biogeográficas.

\section{INTRODUCTION}

Marine biodiversity is threatened by numerous human impacts, such as overfishing, which often results in the removal or drastic decline of high-trophic-level organisms (Pauly and Palomares 2005); activities accelerating climate

\section{INTRODUCCIÓN}

La biodiversidad marina se encuentra amenazada por numerosos impactos humanos, como la sobrepesca, la cual a menudo resulta en la remoción o la drástica disminución de organismos de alto nivel trófico (Pauly y Palomares 
change, which can impact species' ranges and result in local extinctions due to unfavorable conditions; and other forms of pollution and resource extraction that can modify entire communities (Sydeman et al. 2015). Both biodiversity and its threats are not equitably distributed, as some regions have high species richness, unique evolutionary lineages, and a wide variety of covered ecological niches (Costello et al. 2017). Likewise, many areas are subject to greater anthropogenic pressure due to their proximity to highly populated areas, such as islands near the coast (hereafter referred to as continental islands), which are more accessible than remote oceanic islands (Halpern et al. 2019).

Shallow reefs $(<30 \mathrm{~m})$ around islands have been extensively studied (Glynn et al. 2017), while ecosystems at greater depths have received little attention. In particular, the mesophotic zone, which is the layer of the ocean that is between 30 and $150 \mathrm{~m}$ deep in tropical and subtropical waters (Kahng et al. 2019), constitutes one of the least explored zones due to the historically high cost and expertise required to operate tools that can access those depths (Turner et al. 2017). However, although the amount of incident light in this area is low $(1 \%-10 \%$ with respect to the surface) and this limits primary production (Kahng et al. 2019), it is hypothesized that mesophotic reefs could host high biodiversity due to more stable conditions associated with reduced impact of natural (storm damage) and anthropogenic (habitat fragmentation, pollution, overfishing) threats (Loya et al. 2016).

Despite the hypothetical and demonstrated diversity of mesophotic reefs around the world, habitats below $30 \mathrm{~m}$ depth remain severely under-documented in Mexican Pacific waters (Turner et al. 2017). Additionally, the continental islands of this region have been the subject of a greater number of studies compared to the oceanic islands, given the isolation and difficulty in accessing these sites (Quimbayo et al. 2016, Fourriére et al. 2019). For this reason, the present study aimed to characterize the fish assemblages of 2 island groups: continental islands in La Paz Bay, near a large urban center ( $>300,000$ inhabitants), and oceanic islands of the Revillagigedo Archipelago, inhabited only by the population of small naval bases. Using multiple diversity indices, we compared the fish assemblages between different types of habitats in both regions to try to determine whether biogeography, oceanography, and differential exposure to anthropogenic disturbances affects the diversity of ichthyofauna in the mesophotic zone.

Considering the shallow-reef literature for both regions, we developed 5 hypotheses. (1) Species richness would be higher in waters near the islands of La Paz Bay, since it is recognized as a biodiversity hotspot (Olivier et al. 2018). (2) Taxonomic distinctness, which indicates the presence of unique evolutionary lineages, would be greater in continental islands, since older and less isolated island territories are more likely to experience colonization events (Pinheiro et al. 2017). (3) The average trophic level of the oceanic island fish assemblages would be higher due to a lower fishing
2005); actividades que aceleran el cambio climático, que pueden tener efecto en el intervalo de distribución de las especies y dar como resultado extinciones locales por condiciones desfavorables; y otras formas de contaminación y extracción de recursos que pueden modificar comunidades completas (Sydeman et al. 2015). Tanto la biodiversidad como sus amenazas no están distribuidas equitativamente, ya que algunas regiones presentan gran riqueza de especies, linajes evolutivos únicos y amplia variedad de nichos ecológicos cubiertos (Costello et al. 2017). Así mismo, muchas zonas están sometidas a mayor presión antropogénica por su cercanía a zonas altamente pobladas, como las islas cercanas a la costa (continentales), las cuales son más accesibles que las islas remotas (oceánicas) (Halpern et al. 2019).

En territorios insulares, los arrecifes someros $(<30 \mathrm{~m})$ han sido ampliamente estudiados (Glynn et al. 2017), mientras que los ecosistemas arrecifales a mayores profundidades han recibido poca atención. En particular la zona mesofótica, que es la capa del océano que se encuentra entre 30 y $150 \mathrm{~m}$ de profundidad en aguas tropicales y subtropicales (Kahng et al. 2019), constituye uno de los estratos menos explorados del océano debido al costo elevado de operación de las herramientas que permiten su estudio (Turner et al. 2017). Sin embargo, aunque la cantidad de luz incidente en esta zona es reducida ( $1 \%-10 \%$ con respecto a la superficie) y esto limita la producción primaria (Kahng et al. 2019), se considera que los arrecifes mesofóticos podrían albergar gran biodiversidad debido a condiciones más estables asociadas a un menor impacto de disturbios naturales (daño por tormentas) y antropogénicos (fragmentación de hábitat, contaminación y sobrepesca) (Loya et al. 2016).

A pesar de la importancia hipotética y demostrada de los arrecifes mesofóticos alrededor del mundo, en aguas mexicanas del Pacífico los hábitats a profundidades mayores que 30 m aún carecen de descripción alguna (Turner et al. 2017). Adicionalmente, las islas continentales de esta región han sido objeto de un mayor número de estudios en comparación con las islas oceánicas debido a su aislamiento y difícil acceso (Quimbayo et al. 2016, Fourriére et al. 2019). Por ello, el presente estudio tuvo como objetivo caracterizar los ensamblajes de peces de 2 conjuntos insulares: islas continentales en la bahía de $\mathrm{La} \mathrm{Paz}$, cercanas a un gran centro urbano (>300,000 habitantes), así como islas oceánicas del archipiélago de Revillagigedo, habitadas únicamente por la población de pequeñas bases navales. Por medio de índices de diversidad, comparamos los ensamblajes de peces entre diferentes tipos de hábitats de ambas regiones para tratar de determinar si la biogeografía, la oceanografía y la exposición diferencial a disturbios antropogénicos tienen un efecto en la diversidad de la ictiofauna mesofótica.

Con base en la literatura de arrecifes someros de ambas regiones, planteamos 5 hipótesis. (1) La riqueza de especies será mayor en aguas cerca de las islas de la bahía de La Paz, ya que es reconocida como una zona de alta biodiversidad (Olivier et al. 2018). (2) La diferenciación taxonómica 
pressure, since fisheries tend to concentrate on species at higher trophic levels (Pauly and Palomares 2005, Fourriére et al. 2019). (4) The functional diversity observed in oceanic islands would be greater due to the higher occurrence of pelagic species, which present more diverse functions and encompass a greater variety of ecological niches (Robertson and Cramer 2009). (5) All the indices will present higher values in rocky reefs compared to sand habitats, since greater structural complexity can host more diverse fish assemblages (Aburto-Oropeza and Balart 2001).

\section{MATERIALS AND METHODS}

\section{Study area}

The study area included 2 island groups (Fig. 1): the continental islands of Espíritu Santo and Cerralvo, located $<70 \mathrm{~km}$ from the city of $\mathrm{La} \mathrm{Paz} \mathrm{(>300,000} \mathrm{inhabitants)} \mathrm{in} \mathrm{the}$ southern portion of the Gulf of California (CONANP 2015, León-de la Luz and Rebman 2002); and the oceanic islands of San Benedicto, Socorro, and Clarión, located in the Revillagigedo Archipelago ( $>700 \mathrm{~km}$ of the Mexican continental shelf).

The southern Gulf of California, where Espíritu Santo and Cerralvo are located, is a mixing zone of 2 major bodies of surface water (Tropical Surface Water and Gulf of California Water) and the Subtropical Subsurface Water located between 150 and $500 \mathrm{~m}$ deep (Castro et al. 2006). The Revillagigedo Archipelago is influenced by 2 major bodies of water that vary seasonally: in summer there is greater influence of Tropical Surface Water and in winter, the California Current dominates (Portela et al. 2016). Both regions are considered oceanographic transition zones because of the confluences of different water masses (Portela et al. 2016). In addition to the differences in oceanographic conditions between both groups of islands, the classification by Robertson and Cramer (2009) indicates that, considering the resident fish fauna, the continental islands (Espíritu Santo and Cerralvo) belong to the biogeographic province of Cortés, while the Revillagigedo Archipelago is part of the Oceanic Islands province.

The waters surrounding all islands studied are under federal protection in Mexico, with the exception of Cerralvo, where only the land has been federally protected since 1978 (CONANP 2015). The Espíritu Santo marine zone was declared as National Park in 2007 and encompasses a 48,654.83-ha polygon, within which there are 3 no-fishing zones corresponding to $1.4 \%$ of the protected area (CONANP 2015). San Benedicto, Socorro, and Clarión islands are part of the Revillagigedo Archipelago Biosphere Reserve since 1994, which changed to the category of National Park in 2017, covers a polygon of $14,808,780.12$ ha with absolute restriction on fishing activities, and is considered one of the largest protected areas in North America (CONANP 2018). (indicador de presencia de linajes evolutivos únicos) será mayor en islas continentales, ya que territorios insulares más antiguos y menos aislados son más propensos a eventos de colonización (Pinheiro et al. 2017). (3) El nivel trófico promedio de los ensamblajes de peces de las islas oceánicas será mayor por efecto de una menor presión pesquera, la cual generalmente va dirigida a especies de alto nivel trófico (Pauly y Palomares 2005, Fourriére et al. 2019). (4) La diversidad funcional en islas oceánicas será mayor debido a la alta ocurrencia de especies pelágicas, que presentan funciones más diversas y abarcan una mayor variedad de nichos ecológicos (Robertson y Cramer 2009). (5) Los valores de todos los índices serán más altos en el hábitat coralino rocoso en comparación con el arenoso, debido a que una mayor complejidad estructural permite albergar ensamblajes de peces más diversos (Aburto-Oropeza y Balart 2001).

\section{Materiales Y MÉTODOS}

\section{Área de estudio}

El área de estudio incluyó 2 conjuntos insulares de acuerdo a su localización (Fig. 1): las islas continentales Espíritu Santo y Cerralvo, ubicadas en la porción sur del golfo de California, a una distancia de $<70 \mathrm{~km}$ de la ciudad de La Paz (>300,000 habitantes) (CONANP 2015, León-de la Luz y Rebman 2002); y las islas oceánicas San Benedicto, Socorro y Clarión, ubicadas en el archipiélago de Revillagigedo, a una distancia de $>700 \mathrm{~km}$ del macizo continental mexicano.

El sur del golfo de California, en donde se ubican Espíritu Santo y Cerralvo, está sometido a 2 masas de agua superficiales (Agua Tropical Superficial y Agua del Golfo de California) y otra ubicada entre 150 y $500 \mathrm{~m}$ de profundidad (Agua Subtropical Subsuperficial) (Castro et al. 2006). Por su parte, el archipiélago de Revillagigedo está influenciado por 2 masas de agua con variaciones estacionales: en verano hay mayor influencia del Agua Tropical Superficial y en invierno, de la corriente de California (Portela et al. 2016). Ambas regiones se consideran zonas de transición debido a la confluencia de 2 o más masas de agua (Portela et al. 2016). Aunado a las diferencias en condiciones oceanográficas entre ambos conjuntos de islas, la clasificación de Robertson y Cramer (2009) indica que con base en la fauna residente de peces, el conjunto de islas continentales (Espíritu Santo y Cerralvo) pertenece a la provincia biogeográfica de Cortés, mientras que el archipiélago de Revillagigedo es parte de la provincia de Islas Oceánicas.

La porción marina de todas las islas citadas está bajo protección federal en México, excepto Cerralvo, que sólo presenta protección en su porción terrestre desde 1978 (CONANP 2015). La zona marina de Espíritu Santo fue decretada Parque Nacional en 2007 y abarca un polígono de 48,654.83 ha, dentro del que se encuentran 3 zonas de no pesca correspondientes al $1.4 \%$ del área protegida 


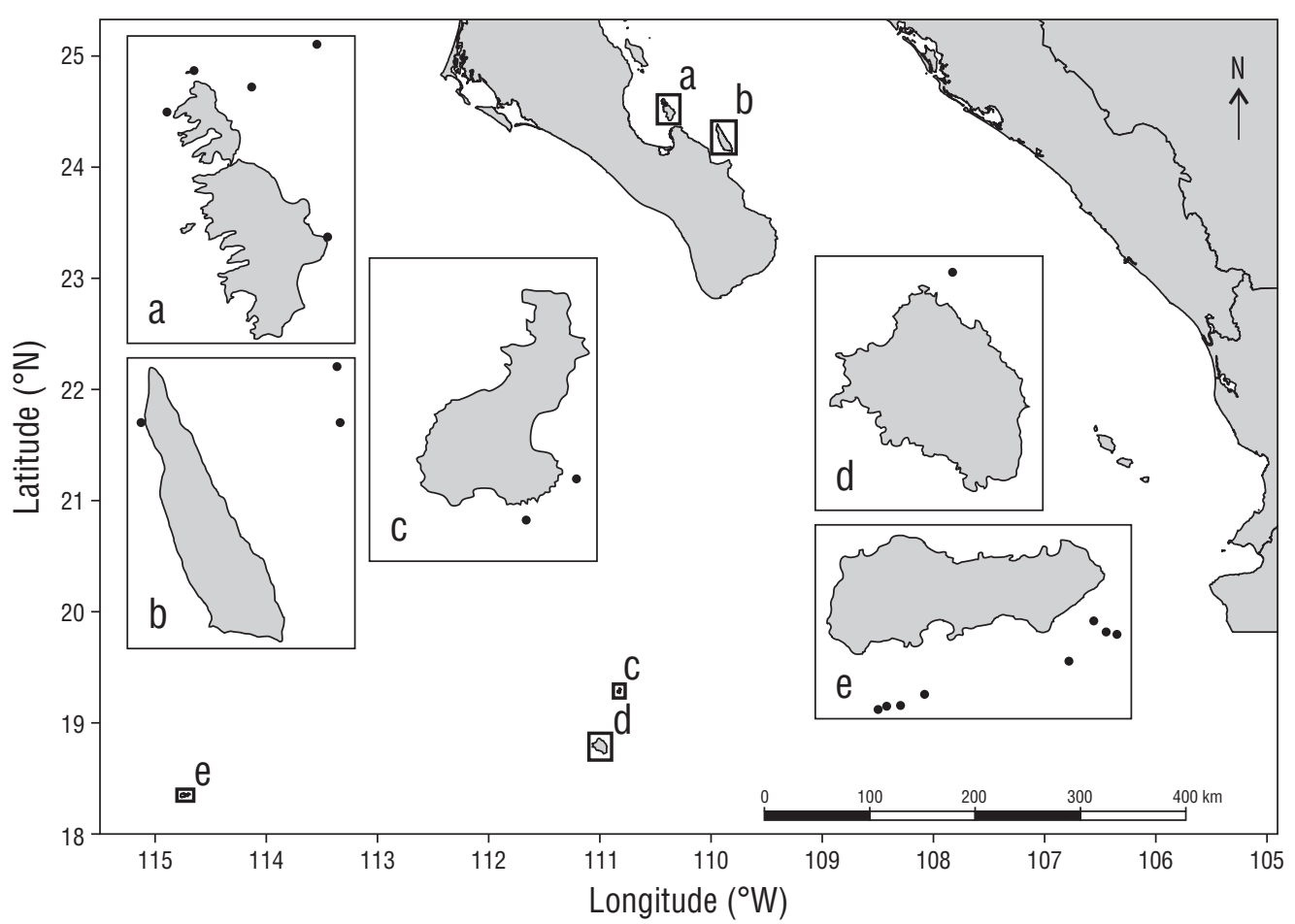

Figure 1. Study area. Continental group: Espíritu Santo (a), Cerralvo (b); oceanic group: San Benedicto (c), Socorro (d), Clarión (e). Black dots indicate survey sites.

Figura 1. Área de estudio. Conjunto continental: Espíritu Santo (a), Cerralvo (b); conjunto oceánico: San Benedicto (c), Socorro (d), Clarión (e). Los marcadores negros indican los sitios de muestreo.

\section{Survey methods}

The study was carried out with a remotely operated vehicle (BlueRobotics, BlueRov2) capable of diving to $100 \mathrm{~m}$. The vehicle was equipped with four 1,500-lm LED lights, an integrated forward facing camera (8 MP, Raspberry Pi v2) with an $80^{\circ}$ angle of view, an external downward-facing camera (GoPro HERO 3 and HERO 4), and a depth $(\mathrm{m})$ and temperature $\left({ }^{\circ} \mathrm{C}\right)$ sensor (Measurements Specialties MS5837-30BA). Although the average speed was not measured, this vehicle could reach a maximum speed of $1.5 \mathrm{~m} \cdot \mathrm{s}^{-1}$. To the best of our abilities, we attempted to hold the vehicle between 1 and $3 \mathrm{~m}$ above the ground for the surveys. In total, we surveyed 20 sites (continental group $N=9$, oceanic group $N=11$; Fig. 1), one dive per survey. The duration of each dive varied between 7 and 65 min depending on the environmental conditions, with a range between 30 and $90 \mathrm{~m}$ depth. The bathymetric range for the mesophotic zone was determined using the literature for subtropical zones (Kahng et al. 2019), because it was not possible to measure the percentage of incident light in situ.

The recordings of both cameras in each dive were synchronized and cut into 5-min segments, starting when the vehicle reached the bottom. Each segment was taken as a sampling unit, which gave a total of 78 video-transects for the 5 islands: 41 video-transects in the continental group (Espíritu Santo $N=31$, Cerralvo $N=10$ ) in October 2018;
(CONANP 2015). Por su parte, las islas San Benedicto, Socorro y Clarión forman parte de la Reserva de la Biosfera Archipiélago de Revillagigedo desde 1994, que cambió a la categoría de Parque Nacional en 2017 y abarca un polígono de 14,808,780.12 ha con restricción absoluta de actividades extractivas, por lo que es considerada una de las áreas protegidas más grandes de Norteamérica (CONANP 2018).

\section{Trabajo de campo}

El estudio se realizó con un vehículo operado remotamente (BlueRobotics, BlueRov2) capaz de sumergirse hasta $100 \mathrm{~m}$ de profundidad. El vehículo estaba equipado con 4 luces LED de 1,500 lm, una cámara integrada en dirección al frente (Raspberry Pi v2 de $8 \mathrm{MP}$ ) con un ángulo de visión de $80^{\circ}$, otra cámara instalada en dirección hacia el fondo (GoPro HERO 3 y HERO 4) y un sensor (Measurements Specialties MS5837-30BA) que midió la profundidad ( $\mathrm{m}$ ) y la temperatura $\left({ }^{\circ} \mathrm{C}\right)$. Aunque no se midió la velocidad promedio, este vehículo alcanza una velocidad máxima de $1.5 \mathrm{~m} \cdot \mathrm{s}^{-1}$. Dentro de nuestras posibilidades, intentamos mantener al vehículo entre 1 y $3 \mathrm{~m}$ sobre el fondo. En total se visitaron 20 sitios (conjunto continental $N=9$, conjunto oceánico $N=11$; Fig. 1) y en cada uno se realizó una inmersión. El tiempo de cada inmersión varío entre 7 y 65 min dependiendo de las condiciones ambientales, con un rango entre 30 y $90 \mathrm{~m}$ de profundidad. El intervalo batimétrico para la zona mesofótica se 
37 video-transects in the oceanic group (Clarión $N=25$, San Benedicto $N=9$, Socorro $N=3$ ) in December 2018 . In each video-transect, all fish within the visual field were identified to the minimum possible taxonomic level using the Robertson and Allen (2015) guide. We estimated the frequency of occurrence of each species (and each class) across each island group, defined as the percentage of video-transects in which each species appeared.

\section{Taxonomic and functional indices}

We constructed species accumulation curves using the number of species observed in each video-transect (S; species richness data) to determine if the sample size per island group was sufficient to adequately characterize the fish assemblage. We also constructed rarefaction curves to compare fish diversity between island groups using species richness and occurrence (Gotelli and Colwell 2001). These curves were made using the exact method (also called Mao Tau) and rarefaction in the vegan package in $\mathrm{R}$ (Oksanen et al. 2019, R Core Team 2019).

We calculated the average taxonomic distinctness $\left(\Delta^{+}\right)$ per video-transect using the taxonomic level of each species observed. This index assesses the degree of taxonomic relatedness among the species of an assemblage according to the Linnaean classification tree, including 6 hierarchical levels (genus, family, order, subclass, class, and superclass; Clarke and Warwick 1998; Table S1). Based on analysis by Clarke and Warick (1998), this metric is capable of detecting the effect of anthropogenic disturbances that tend to remove the most taxonomically different species first, due to their low frequency of occurrence. The species that remain tend to be more common and are usually more taxonomically similar, so low values are associated with more homogeneous communities. This index has advantages for ecological studies, such as independence from the sampling effort and not requiring normality in the data (Clarke and Warwick 1998). To complement this analysis, we created a funnel plot based on random simulations of the data to calculate the expected value of $\Delta^{+}$ and its interval using the number of species observed in each sample. This allowed us to compare observed vs. expected taxonomic distinctness. Calculations were made using the vegan package in $\mathrm{R}$ (Oksanen et al. 2019).

Average trophic level (NT) per video-transect was calculated using the trophic level value for each observed species, as taken from FishBase (Froese and Pauly 2019), and divided by the number of species per video-transect (Pauly and Palomares 2005; Table S1). Trophic level values refer to the position of species in the food web, including herbivores and detritivores (2.00-2.19), planctivores and secondary consumers (2.20-2.79), benthic carnivores (2.80-3.90), and piscivores or predators (4-5; Pauly and Palomares 2005, Fourriére et al. 2019). NT can illustrate the effect of fisheries on the assemblage, given that catches often target high trophic level species. determinó con base en literatura de zonas subtropicales (Kahng et al. 2019), debido a que no fue posible medir in situ el porcentaje de luz incidente.

Las grabaciones de ambas cámaras en cada inmersión se sincronizaron y se cortaron cada $5 \mathrm{~min}$, a partir de que el vehículo alcanzó el fondo. Cada segmento de 5 min fue tomado como unidad de muestreo, lo que dio un total de 78 video-transectos para las 5 islas: 41 video-transectos para el conjunto continental (Espíritu Santo $N=31$, Cerralvo $N=10$ ) en octubre de 2018; 37 video-transectos para el conjunto oceánico (Clarión $N=25$, San Benedicto $N=9$, Socorro $N=3$ ) en diciembre de 2018. En cada video-transecto se identificaron los peces dentro del campo visual al mínimo taxón posible usando la guía de Robertson y Allen (2015). Con base en la presencia de las especies, se estimó su frecuencia de ocurrencia en cada conjunto insular, el cual fue definido como el número de video-transectos en el que apareció cada especie (y cada clase) con respecto al total (expresado en porcentaje).

\section{Índices taxonómicos y funcionales}

A partir de los datos de riqueza de especies (S; número de especies observadas en cada video-transecto), se realizaron curvas de acumulación para determinar si el tamaño de muestra por conjunto insular fue significativo para caracterizar adecuadamente el ensamblaje de peces. Además, se realizaron curvas de rarefacción para comparar la diversidad de peces entre conjuntos insulares a partir de la riqueza y ocurrencia de especies (Gotelli y Colwell 2001). Estas curvas se realizaron con el método exact (también llamado Mao Tau) y rarefaction del paquete vegan (Oksanen et al. 2019) en lenguaje de programación R (R Core Team 2019).

Adicionalmente, se calculó la diferenciación taxonómica promedio $\left(\Delta^{+}\right)$por video-transecto utilizando la jerarquía taxonómica de cada especie observada. Este índice evalúa el grado de relación taxonómica entre las especies de un ensamblaje de acuerdo con un árbol de clasificación linneana, para el que se tomaron 6 niveles jerárquicos (género, familia, orden, subclase, clase y superclase; Clarke y Warwick 1998; Tabla S1); este índice es capaz de detectar el efecto de disturbios antropogénicos que tienden a remover primero las especies más diferentes taxonómicamente, debido a que presentan baja frecuencia de ocurrencia. Por su parte, las especies que permanecen presentan alta frecuencia de ocurrencia y suelen ser más similares en términos taxonómicos, por lo que bajos valores se asocian con comunidades más homogéneas. Este índice presenta ventajas para los estudios ecológicos, como la independencia al esfuerzo de muestreo y el no requerir normalidad en los datos (Clarke y Warwick 1998). Para complementar este análisis, se realizó una gráfica de embudo a partir de simulaciones aleatorias de los datos para calcular el valor esperado de $\Delta^{+}$y su intervalo con base en el número de especies observadas en cada muestra. Esto permite comparar la diversidad observada con 
Functional indices were calculated from 6 traits that reflect key aspects of fish ecology (Olivier et al. 2018): (1) maximum length (ordinal: $0-7,7-15,15-30,30-50,50-80$, $>80 \mathrm{~cm}$ ), (2) mobility (ordinal: highly attached to the site, mobile with a small home range, mobile with a large home range, highly mobile with a very large home range), (3) period of activity (nominal: day, night), (4) gregariousness (ordinal: solitary, in pairs, small and large schools), (5) position in the water column (ordinal: benthic, benthopelagic, pelagic), and (6) diet (nominal: herbivore-detritivore, invertivore of sessile organisms, invertivore of mobile organisms, planktivore, piscivore, omnivore). For the species that were not listed by Olivier et al. (2018), we obtained the functional information from FishBase (Froese and Pauly 2019) and Shorefishes of the Tropical Eastern Pacific (Robertson and Allen 2015) databases. With the functional traits, we generated an alphanumeric code to define the group or functional entity (FE; Table S2) of each species. In addition, with these codes, we calculated the richness of FEs per island group, which corresponds to the number of unique combinations of traits present in a given assemblage (Mouillot et al. 2014).

To calculate the functional volume per island group in each habitat, the matrix of functional traits per species (nominal and ordinal) was transformed into a quantitative similarity matrix using the Gower distance coefficient, which allows to compare different types of variables and give them equal weight (Gower 1971). Subsequently, a principal coordinate analysis (PCoA) was performed to transform these distances into coordinates. The coordinates by species were used to estimate the functional volume according to the model of Cornwell et al. (2006) (convex hull volume), in which the outermost vertices (represented by the FEs with more atypical traits) define the convex hull (Villéger et al. 2008). The number of coordinates used to represent the functional space per island group in each habitat (first four) was selected based on the criteria of Maire et al. (2015).

Finally, the values of these 4 coordinates per species in each video-transect were used to calculate the average functional richness (FRic), which corresponds to the amount of functional space that an assemblage encompasses in each video-transect, in proportion to the regional volume (Villéger et al. 2008; Table S1). Low FRic values indicate that there are niches (i.e., resources) in the community that are not occupied or exploited (Mason et al. 2005). This index, as well as the functional volume (i.e., the space covered by the assemblage in each island group) and the number of FEs, was calculated using the packages $F D$ (Laliberté et al. 2014), tripack (Renka et al. 2020), and geometry (Roussel et al. 2019). It is necessary to highlight that functional diversity studies complement analyses that rely on traditional indices, since incorporating information on biological traits makes it possible to identify the role of each species in ecosystem processes (Petchey et al. 2007, Francisco and de la Cueva 2017). Thus, assemblages belonging to disturbed or degraded habitats will present a lower variety of processes (and therefore lower la esperada. Los cálculos se realizaron con el paquete vegan de R (Oksanen et al. 2019)

Se determinó el nivel trófico promedio (NT) utilizando los valores de nivel trófico por especie obtenidos de FishBase (Froese y Pauly 2019) y divididos entre el número de especies por video-transecto (Pauly y Palomares 2005; Tabla S1). Los valores del nivel trófico indican la posición de las especies en la cadena trófica, la cual incluye herbívoros y detritívoros (2.00-2.19), planctívoros y consumidores secundarios (2.20-2.79), carnívoros bentónicos (2.80-3.90) y piscívoros o depredadores (4-5; Pauly y Palomares 2005, Fourriére et al. 2019). El NT puede ilustrar el efecto de las pesquerías en el ensamblaje, ya que las capturas regularmente se dirigen a las especies de alto nivel trófico.

Los índices funcionales se calcularon a partir de 6 atributos que describen papeles clave en la ecología de peces (Olivier et al. 2018): (1) talla máxima (ordinal: 0-7, 7-15, 15-30, 30-50, 50-80, >80 cm), (2) movilidad (ordinal: altamente unida al sitio, móviles con una distribución de hogar pequeña, móviles con una distribución de hogar amplia, altamente móviles con una distribución de hogar muy amplia), (3) periodo de actividad (nominal: diurno, nocturno), (4) grado de agregación (ordinal: solitario, en pares, pequeños y grandes cardúmenes), (5) posición en la columna de agua (ordinal: bentónico, bentopelágico, pelágico) y (6) dieta (nominal: herbívoro-detritívoro, invertívoro de organismos sésiles, invertívoro de organismos móviles, planctívoro, piscívoro, omnívoro). Para las especies que no fueron registradas en el estudio de Olivier et al. (2018), se obtuvo la información funcional de las bases de datos FishBase (Froese y Pauly 2019) y Shorefishes of the Tropical Eastern Pacific (Robertson y Allen 2015). Con los atributos, se generó una clave alfanumérica que define el grupo o entidad funcional (FE; Tabla S2) al que pertenece cada especie, y con ella, se calculó la riqueza de FE por conjunto insular, que corresponde al número de combinaciones únicas de atributos presentes en un ensamblaje dado (Mouillot et al. 2014).

Para el cálculo del volumen funcional por conjunto insular en cada hábitat, se transformó la matriz de atributos funcionales por especie (nominal y ordinal) en una matriz de similitud cuantitativa, por medio del coeficiente de distancia de Gower, el cual permite comparar variables de diferentes tipos y les da igual peso (Gower 1971). Posteriormente, se realizó un análisis de coordenadas principales (PCoA, por sus siglas en inglés) para transformar estas distancias en coordenadas. Las coordenadas por especie se utilizaron para estimar el volumen funcional de acuerdo al modelo de Cornwell et al. (2006) (convex hull volume), en el cual los vértices más externos (representados por las $\mathrm{FE}$ con atributos más atípicos) definen el perímetro funcional (Villéger et al. 2008). El número de coordenadas utilizadas para representar el espacio funcional por conjunto insular en cada hábitat (primeras cuatro) fue seleccionado con base en los criterios de Maire et al. (2015). 
values of functional diversity), compared to pristine habitats (Villéger et al. 2010).

\section{Statistical analysis}

Using generalized Bayesian linear mixed models, we evaluated whether the calculated diversity indices $\left(\mathrm{S}, \Delta^{+}, \mathrm{NT}\right.$, and FRic) varied according to the island group (oceanic or continental) and/or type of habitat (sand or rocky reef). Island group and habitat were modeled as fixed effects and their interaction was also considered. On the other hand, the island $(N=5)$ and site $(N=20)$ variables were included as random effects. All indices were modeled using a Gaussian distribution, with the exception of S, which was modeled using a Poisson distribution. The treatments (island group, habitat, and interaction) were considered different if the $95 \%$ credible interval of the posterior distribution did not overlap the value of zero. The models were run using the brms package (Bürkner 2018), and they used Monte Carlo-type simulation methods, 4 Markov chains, non-informative priors, and a subsequent analysis period of 4,000 cycles. The convergence of each model was evaluated based on well-mixed sampling chains and rhat values equal to one. Finally, we conducted an a posteriori Tukey test to compare the distributions of the fixed effects in a paired way, using the emmeans package (Lenth 2019).

\section{Results}

In total, we identified 73 species ( 8 of them only at the genus level), which included 65 bony fish ( 25 families and 47 genera) and 8 cartilaginous fish species ( 3 families and 5 genera) in the $13 \mathrm{~h}$ of video surveys. The class Actinopterygii had the highest frequency of occurrence for both island groups. Bony fish occurred in $>94 \%$ of the video-transects in the continental group, and the dominant species were Holacanthus passer ( $>18 \%$ of video-transects), Liopropoma fasciatum $(>12 \%)$, and Paranthias colonus $(>12 \%)$. In the oceanic group, Actinopterygii were present in $77 \%$ of video-transects over rocky habitat and $86 \%$ of video-transects over sandy habitat, with the most frequently observed species being Paranthias colonus ( $>57 \%$ of video-transects), Caranx lugubris (>53\%), and Seriola rivoliana (>23\%) (Table S2). In general, the class Elasmobranchii was much less common. In the continental group, it was observed in only $4 \%$ of video-transects over rocky habitats and $6 \%$ over sandy habitats, with the Urobatis (4\%) and Urotrygon (6\%) genera as the most frequent. In the oceanic group, this class was observed in $14 \%$ of the video-transects conducted over sandy habitat and $23 \%$ of the video-transects over rocky habitat. In rocky oceanic habitats, sharks such as Carcharhinus albimarginatus (40\%) and Carcharhinus falciformis (37\%) were the most frequently observed (Table S2).

The accumulation curves for both island groups were asymptotic (Fig. 2), meaning that the sample size adequately
Por último, los valores de estas 4 coordenadas por especie en cada video-transecto se utilizaron para calcular la riqueza funcional promedio (FRic), que corresponde a la cantidad de espacio funcional que abarca un ensamblaje (en este caso cada video-transecto) en proporción al volumen total de la región (Villéger et al. 2008; Tabla S1). Bajos valores de FRic indican que en la comunidad hay nichos/recursos disponibles que no son ocupados/aprovechados (Mason et al. 2005). Este índice, al igual que el volumen funcional (i.e., el espacio abarcado por el ensamblaje en cada conjunto insular) y el número de $\mathrm{FE}$, se calculó con los paquetes $F D$ (Laliberté et al. 2014), tripack (Renka et al. 2020) y geometry (Roussel et al. 2019). Es necesario resaltar que los estudios de diversidad funcional complementan los análisis con índices tradicionales, ya que el incorporar información de atributos biológicos permite identificar el papel de las especies en los procesos ecosistémicos (Petchey et al. 2007, Francisco y de la Cueva 2017). Así, ensamblajes pertenecientes a hábitats perturbados o degradados presentarán una menor variedad de procesos (y por lo tanto menores valores de diversidad funcional), en comparación con hábitats prístinos (Villéger et al. 2010).

\section{Análisis estadístico}

Mediante modelos lineales generalizados mixtos bayesianos, evaluamos si los índices de diversidad calculados ( $\mathrm{S}$, $\Delta^{+}$, NT y FRic) variaron según el conjunto insular (oceánico o continental) y/o el tipo de hábitat (arena o arrecife rocoso). Tanto el conjunto insular como el hábitat fueron incorporados como efectos fijos individuales, y también se consideró su interacción. Por otro lado, las variables isla $(N=5)$ y sitio $(N=20)$ se incluyeron como efectos aleatorios. Todos los índices fueron modelados usando una distribución gaussiana, con la excepción de S, que fue modelada usando una distribución de Poisson. Los tratamientos (conjunto insular, hábitat e interacción) fueron considerados diferentes si el intervalo creíble al 95\% de la distribución posterior no traslapó el valor de cero. Los modelos se ejecutaron utilizando el paquete brms (Bürkner 2018) empleando métodos de simulación de tipo Monte Carlo, 4 cadenas de Markov, antecedentes no informativos y un periodo posterior de análisis de 4,000 ciclos. La convergencia de cada modelo se evaluó con base en cadenas de muestreo bien mezcladas y valores rhat igual a uno. Finalmente, utilizamos la prueba a posteriori de Tukey para comparar las distribuciones de los efectos fijos de manera pareada, con el paquete emmeans (Lenth 2019).

\section{Resultados}

En total se identificaron 73 especies ( 8 de ellas solo a nivel de género): 65 peces óseos ( 25 familias y 47 géneros) y 8 cartilaginosos ( 3 familias y 5 géneros) en las $13 \mathrm{~h}$ de muestreo con video. La clase Actinopterygii tuvo la mayor frecuencia de ocurrencia en ambos conjuntos insulares. En 
represented the actual fish assemblages. The rarefaction curves indicated less dominance of a few species and therefore more diversity in the oceanic islands, compared to the continental group (Fig. 2). Additionally, the funnel plot of $\Delta^{+}$suggested that both island groups had values lower than would be expected given the number of species observed in each video-transect (Fig. S1). This pattern was especially observed in the continental group, which indicates that the fish assemblages in this area are taxonomically less complex than would be expected.

For the $\mathrm{S}, \Delta^{+}$, and NT indices, we found no differences between the oceanic and continental assemblages and no interaction between island group and habitat (Table S3). However, we did see an effect of habitat, with higher average values for rocky reefs compared to sandy habitats (Table S3). In contrast, for FRic we found an effect of the habitat and the interaction between island group and habitat. The a posteriori test showed that, within the oceanic group, video-transects from rocky reefs had higher average FRic values than those in sandy habitats, while there was no difference between habitats in the continental group. No difference was observed between the island groups (Table 1).

Finally, regarding the number FEs and the functional space occupied (Fig. 3), we observed higher values among rocky reefs compared to sandy habitats in both island groups. Among the oceanic group, we observed 40 FEs and $76 \%$ of functional space occupied in rocky reefs and $19 \mathrm{FEs}$ and $44 \%$ of functional space occupied in sandy habitats. Similarly, in the continental group we observed a higher number of FEs (37 FEs) and functional space occupied (66\%) in rocky reefs than in sandy habitats (22 FEs and $42 \%$ functional space occupied).

\section{Discussion}

In this study, we analyzed the fish biodiversity observed at mesophotic depths around island clusters in 2 biogeographic provinces on the Pacific coast of Mexico. Despite the fact that oceanographic conditions, proximity to human populations, and levels of protection against resource extraction were dramatically different between both island groups, we did not find differences in most of the diversity indices tested. This result was the opposite of that reported by Ramírez-Ortiz et al. (2017), where they found significant differences in the richness and functional diversity of shallow fish and invertebrates between both provinces, with higher values in the province of Cortés compared to the Oceanic Islands province. This pattern was associated to the presence of more heterogeneous areas in the Gulf of California (Cortés), in terms of oceanographic conditions and habitat, which offered a greater variety of environments and niche spaces for different species compared with the Oceanic Islands province.

Part of the difference between the study by RamírezOrtiz et al. (2017) and ours could be attributed to the fact that our analysis included only conspicuous medium and el conjunto continental, los peces óseos tuvieron $>94 \%$ de frecuencia de ocurrencia en ambos hábitats y las especies más destacadas fueron Holacanthus passer (>18\%), Liopropoma fasciatum (>12\%) y Paranthias colonus $(>12 \%)$. En el conjunto oceánico, esta clase representó el $77 \%$ en el hábitat rocoso y $86 \%$ en el arenoso, y destacaron las especies Paranthias colonus ( $>57 \%)$, Caranx lugubris $(>53 \%)$ y Seriola rivoliana (>23\%) (Tabla S2). En general, la clase Elasmobranchii fue menos común. En el conjunto continental presentó el $4 \%$ de frecuencia de ocurrencia en hábitats rocosos y $6 \%$ en hábitats arenosos, con los géneros Urobatis (4\%) y Urotrygon (6\%) como los más frecuentes. En el conjunto oceánico, este taxón presentó el 14\% de frecuencia de ocurrencia en zonas arenosas, y $23 \%$ en arrecifes rocosos. Cabe destacar que en hábitats rocosos oceánicos, los tiburones como Carcharhinus albimarginatus (40\%) y Carcharhinus falciformis (37\%) presentaron alta frecuencia de ocurrencia (Tabla S2).

Las curvas de acumulación de ambos conjuntos insulares presentaron un comportamiento asintótico (Fig. 2), lo que quiere decir que el tamaño de muestra representó adecuadamente los ensamblajes de peces mesofóticos. Por su parte, las curvas de rarefacción mostraron que hubo menor dominancia de pocos individuos $\mathrm{y}$, por tanto, más diversidad en el conjunto oceánico, en comparación con el conjunto continental (Fig. 2). Adicionalmente, la gráfica de embudo de $\Delta^{+}$ determinó que ambos conjuntos de islas presentaron valores por debajo de lo esperado dado el número de especies observadas en cada video-transecto (Fig. S1). La mayoría de estos censos pertenecieron al conjunto continental, lo que indica que los ensamblajes de peces ahí son taxonómicamente menos complejos de lo esperado.

Para los índices $\mathrm{S}, \Delta^{+}$y NT, no encontramos diferencias entre el conjunto oceánico y el continental, ni tampoco para la interacción conjunto insular y hábitat (Tabla S3). Sin embargo, se observó un efecto del hábitat, con mayores valores promedio en arrecifes rocosos en comparación con zonas arenosas (Tabla S3). En contraste, para FRic, encontramos un efecto del hábitat y la interacción conjunto insular y hábitat. La prueba a posteriori mostró que los arrecifes rocosos del conjunto oceánico presentaron mayores valores promedio de FRic en comparación con los de los hábitats arenosos (Tabla 1), pero no encontramos diferencias con respecto a ambos hábitats del conjunto continental. Cabe mencionar que para este índice, tampoco se encontraron diferencias entre los conjuntos insulares (Tabla 1).

Por último, en cuanto al número de $\mathrm{FE}$ y el espacio funcional ocupado (Fig. 3), se observaron mayores valores entre los arrecifes rocosos en comparación con los hábitats arenosos de ambos conjuntos insulares. En el conjunto oceánico, los arrecifes rocosos presentaron $40 \mathrm{FE} \mathrm{y} 76 \%$ de espacio funcional ocupado y los hábitats arenosos presentaron $19 \mathrm{FE}$ y $44 \%$ de espacio funcional ocupado. De manera similar el conjunto continental presentó mayores valores de FE (37 FE) y espacio funcional ocupado (66\%) en zonas 
large ichthyofauna, since these were readily identifiable in the video-transects. In contrast, Ramírez-Ortiz et al. (2017) included invertebrates and some cryptic fish, which may contribute to the richness and functional diversity values reported in both regions in highly meaningful ways. Likewise, their analysis was based on an extensive sampling effort that covered a wider range of environments in the Gulf of California (Los Cabos, Cabo Pulmo, Espíritu Santo, Loreto), whereas our study included only areas in the immediate surroundings of Espíritu Santo and Cerralvo. Considering the high variability we observed between islands and sites, further exploration will be necessary to effectively capture the range of habitats and assemblages at mesophotic depths in both island groups. Although technological advances will increase accessibility to the mesophotic zone to allow for more robust comparisons with shallow reefs, this work is a first step towards that goal.

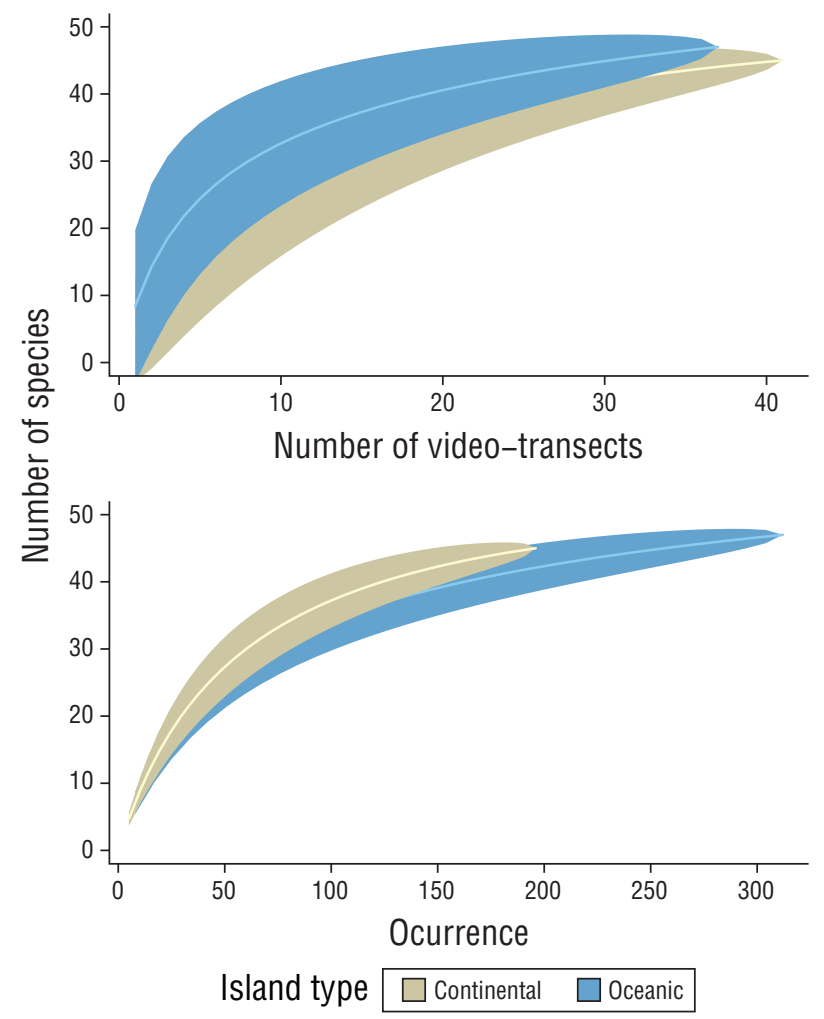

Figure 2. Species accumulation curves and rarefaction curves by island group. For the accumulation curves, the independent variable is the number of video-transects and the dependent variable is the number of accumulated species. For the rarefaction curves, the independent variable is occurrence, and the dependent variable is the number of species.

Figura 2. Curvas de acumulación de especies y curvas de rarefacción por conjunto insular. En las curvas de acumulación, la variable independiente es el número de video-transectos realizados y la variable dependiente es el número de especies acumuladas. En las curvas de rarefacción, la variable independiente es la ocurrencia y la variable dependiente es el número de especies. rocosas que en zonas arenosas (22 FE y 42\% de espacio funcional ocupado).

\section{Discusión}

En el presente estudio analizamos la biodiversidad de peces en los ecosistemas mesofóticos insulares de 2 provincias biogeográficas de la costa mexicana del Pacífico. A pesar de que las condiciones oceanográficas, la proximidad a las poblaciones humanas y los niveles de protección contra la extracción de recursos fueron dramáticamente diferentes entre ambos conjuntos insulares, no encontramos diferencias en la mayoría de los índices de diversidad. Este resultado fue opuesto a lo reportado por Ramírez-Ortiz et al. (2017), quienes encontraron diferencias significativas en la riqueza y la diversidad funcional de peces e invertebrados someros entre ambas provincias, con mayores valores en la provincia de Cortés en comparación con la provincia de Islas Oceánicas. Este hecho lo atribuyeron a que el golfo de California (Cortés) es una de las zonas más heterogéneas en el área de estudio, en términos de condiciones oceanográficas y hábitat, lo que ofrece gran variedad de ambientes para distintas especies.

La diferencia entre el trabajo de Ramírez-Ortiz et al. (2017) y el de nosotros se debe, en parte, a que nuestro estudio sólo incluyó ictiofauna conspicua de talla mediana/ grande, debido a que es fácilmente identificable en los video-transectos. En contraste, Ramírez-Ortiz et al. (2017) reportaron invertebrados y algunos peces crípticos, lo que pudo contribuir de manera importante a los valores de riqueza y diversidad funcional reportados para ambas regiones. Así mismo, su análisis se basó en un amplio esfuerzo de muestreo que abarcó más ambientes en el golfo de California (Los Cabos, Cabo Pulmo, Espíritu Santo y Loreto), mientras que nuestro estudio incluyó sólo zonas circundantes a Espíritu Santo y Cerralvo. Tomando en cuenta la gran variabilidad que observamos entre islas y sitios muestreados, será necesario realizar más exploraciones para capturar de manera efectiva la distribución de hábitats y ensamblajes mesofóticos en ambos conjuntos insulares. Si bien, los avances tecnológicos aumentarán la accesibilidad a profundidades mesofóticas para hacer comparaciones más sólidas con arrecifes someros, el presente trabajo constituye un primer paso hacia ese objetivo.

Los resultados para todos los índices (Tabla S3) coinciden con el efecto del hábitat en la diversidad de peces, lo que confirma nuestra quinta hipótesis de trabajo (mayor diversidad en hábitats rocosos) y complementa el análisis de Hollarsmith et al. (2020). Aunado a ello, otros análisis han destacado que la rugosidad es la característica que tiene mayor efecto en la diversidad de la ictiofauna (Kelley et al. 2006, Dustan et al. 2013); aunque dicha variable no fue directamente cuantificada, era visualmente obvio que las zonas arenosas (homogéneas y con mínimo relieve) eran tridimensionalmente menos complejas que los arrecifes rocosos. 
Table 1. Results of Tukey tests for the Bayesian generalized linear mixed models, including the estimated value and the $95 \%$ credible interval (CI) by island group (difference between continental and oceanic), habitat (difference between rock and sand), and the interaction between island group and habitat (difference between rock and sand in continental vs. oceanic islands). Factors in bold indicate a significant effect (i.e., CI does not overlap zero).

Tabla 1. Resultados de las pruebas de Tukey de los modelos generalizados mixtos bayesianos que incluyen el valor estimado y el intervalo creíble al 95\% (CI) por conjunto insular (diferencia entre continental y oceánico), hábitat (diferencia entre arrecife rocoso y zona arenosa) y la interacción entre conjunto insular y hábitat (diferencia entre arrecife rocoso y zona arenosa en islas continentales $v s$. oceánicas). Los factores en negritas indican un efecto significativo (i.e., CI no se sobrepone al cero).

\begin{tabular}{lrr}
\hline & Estimate & 95\% CI \\
\hline Species richness & & \\
Island group & -1.53 & -3.97 to 1.86 \\
Habitat & $\mathbf{3 . 6 7}$ & $\mathbf{2 . 4 5}$ to $\mathbf{5 . 4 7}$ \\
Island group $\times$ habitat & -1.29 & -2.77 to 1.79
\end{tabular}

Average taxonomic distinctness

Island group

\section{Habitat}

Island group $\times$ habitat

Trophic level

Island group

Habitat

Island group $\times$ habitat

Functional richness

Island group

Habitat

Island group $\times$ habitat

$$
-14.20
$$

33.60

$-5.72$

$\begin{array}{ll}-0.82 & -2.27 \text { to } 0.59 \\ \mathbf{0 . 5 6} & -\mathbf{0 . 0 3} \text { to } \mathbf{1 . 1 4} \\ 0.91 & -0.20 \text { to } 2.13\end{array}$

-34.20 to 7.33

20.20 to 47.10

-30.80 to 20.80
Across all assessed indices (Table S3), we found that habitat influences fish assemblages, which confirmed our fifth working hypothesis (greater diversity in rock habitats) and complemented the analysis of Hollarsmith et al. (2020). In addition to this, other analyses have highlighted that structural complexity (rugosity) is the characteristic that has the greatest effect on the diversity of ichthyofauna (Kelley et al. 2006, Dustan et al. 2013). Although this variable was not directly quantified, it was visually obvious that the sandy areas (homogeneous and with minimal rugosity) were three-dimensionally less complex than the rocky reefs.

In regard to differences in mesophotic fish assemblages between the island groups, and thus differences between the biogeographic provinces, we rejected our working hypotheses 1, 2, and 3. Traditional indices $\left(\mathrm{S}, \Delta^{+}\right.$, and NT) did not present significant differences between island groups,
En cuanto a si los ensamblajes de peces en arrecifes mesofóticos presentaron diferencias según el conjunto insular, y por tanto entre provincias biogeográficas, rechazamos nuestras hipótesis de trabajo 1, 2 y 3 . Los índices tradicionales $\left(\mathrm{S}, \Delta^{+}\right.$y NT) no presentaron diferencias entre conjuntos insulares, lo cual indica que, aunque las especies difieran (Hollarsmith et al. 2020), la diversidad de la ictiofauna mesofótica fue prácticamente homogénea. Esto puede deberse a que el menor impacto de disturbios naturales y antropogénicos con respecto a la profundidad (Loya et al. 2016) podría favorecer condiciones similares en los estratos mesofóticos de ambas provincias biogeográficas y, por tanto, una ictiofauna con diversidad y niveles de conservación semejantes (Clarke y Warwick 1998, Pauly y Palomares 2005).

Se debe tomar en cuenta que los índices tradicionales $\left(\mathrm{S}, \Delta^{+}\right.$y NT) no consideran la identidad de las especies (a 
indicating that, although the species themselves differed (Hollarsmith et al. 2020), the fish assemblages of the mesophotic zone were homogenous. This may be due to the fact that these depths are impacted by fewer natural and anthropogenic disturbances (Loya et al. 2016), which could mean similar conditions across both biogeographic provinces that could support fish assemblages with similar diversity and conservation status (Clarke and Warwick 1998, Pauly and Palomares 2005).

Given that traditional indices ( $\mathrm{S}, \Delta^{+}$, and NT) do not consider the identity of the species (despite incorporating information on the taxonomic hierarchy and trophic level), a further analysis, such as the calculation of functional richness (which incorporates information on functional traits), pesar de incorporar información de jerarquía taxonómica y nivel trófico), por lo que fue necesario realizar un análisis de riqueza funcional (que incorpora información de los atributos funcionales) para confirmar si ambos conjuntos insulares en los 2 tipos de hábitat analizados presentaban una diversidad de peces similar (Tabla S4). En este caso, la riqueza funcional mostró un patrón diferente al de los demás índices: los ensamblajes de peces observados en arrecifes rocosos del conjunto oceánico abarcaron un mayor volumen funcional en comparación con hábitats arenosos del mismo conjunto (Fig. 3). Dado que el volumen funcional está definido por los vértices (representados por las $\mathrm{FE}$ con más atributos atípicos) más exteriores del ensamblaje, mayores valores de este índice señalan que una distribución más amplia de
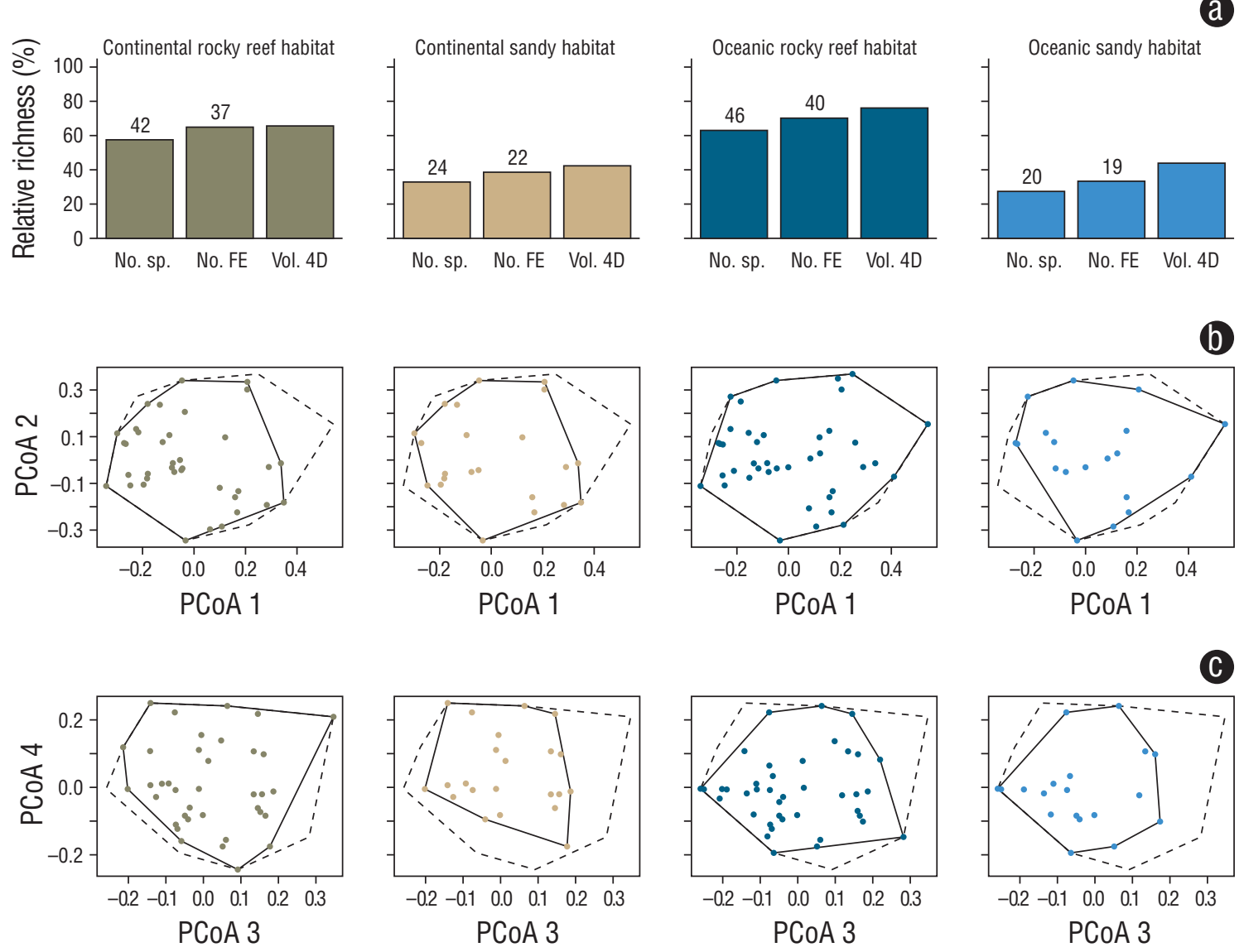

Figure 3. Functional space occupied by the ichthyofauna at mesopthotic depths across both island groups (continental and oceanic) for the 2 habitats (rock and sand). In the first row (a), histograms of species richness (No. sp.), number of functional entities (No. FE), and percentage of occupied functional space (Vol. 4D) are presented (absolute value displayed at the top of each bar). The next 2 rows represent the distribution of the species recorded in the functional space, constructed from axes 1 and 2 (b), and axes 3 and 4 (c) of the PCoA. The volume occupied by the functional entities of each island group and habitat is framed in black and the regional space is shown with a black dashed line.

Figura 3. Espacio funcional ocupado por la ictiofauna de arrecifes mesofóticos de ambos conjuntos insulares (continental y oceánico) para los 2 hábitats (arrecife rocoso y zona arenosa). En la primera fila (a) se presentan histogramas de la riqueza de especies (No. sp.), número de entidades funcionales (No. FE) y porcentaje del espacio funcional ocupado (Vol. 4D) (valor absoluto desplegado en la parte superior de cada barra). Las siguientes 2 filas representan la distribución de las especies registradas en el espacio funcional, construido a partir de los ejes 1 y 2 (b), y ejes 3 y 4 (c) del PCoA. El volumen ocupado por las entidades funcionales de cada conjunto insular y hábitat está enmarcado en color negro y el espacio regional se muestra con línea punteada negra. 
was necessary to confirm if fish assemblages in the 2 types of habitats in both island groups showed similar fish diversity (Table S4). In this case, functional richness showed a different pattern than the other indices: the fish assemblages observed in rocky reefs around the oceanic group occupied a greater functional volume compared to sandy habitats of the same group (Fig. 3). Considering that the functional volume is defined by the outermost vertices (represented by the FEs with more atypical traits) of the assemblage, higher values of this index indicate that the rocky reefs supported a wider range of functional niches in the oceanic group (Mouillot et al. 2014). The differences between both habitats were also observed in the total functional volume covered by each assemblage (Fig. 3), where the rocky reef habitat of the oceanic group comprised $76 \%$ of the regional volume, compared to $44 \%$ occupied by the assemblage found in sandy habitats.

The observed higher functional volume in the rock habitats around the oceanic group was likely driven by the high frequency of occurrence of elasmobranchs and transpacific species in rocky reefs of the Revillagigedo Archipelago (23\%; Table S2). The extreme functional characteristics of sharks relative to other ichthyofauna can greatly increase the functional heterogeneity of an assemblage (Clarke and Warwick 1998, Rogers et al. 1999). In addition to elasmobranchs, the resident fauna of these rock habitats on oceanic islands is enriched by a great variety of transpacific species (Robertson and Cramer 2009), which are mostly benthopelagic. These species are often large, highly mobile, and with wide distributions, which would also increase functional heterogeneity, and thus total functional volume and richness, of an assemblage. This pattern has also been observed around other oceanic islands of the Eastern Tropical Pacific (Malpelo; Quimbayo et al. 2016). Importantly, many of these species with extreme traits and high frequency of occurrence ( $>23 \%$; Table S2), such as Caranx lugubris and Seriola rivoliana, also make up economically important fisheries in Mexico (DOF 2018).

The preponderance of sharks and commercially important fish species in rocky reef habitats around the oceanic islands could indicate reduced fishing pressure in the region. Fishing exploitation tends to first remove large and high-trophiclevel species given their high commercial value (Pauly and Palomares 2005). The remoteness of the Revillagigedo Archipelago ( $>700 \mathrm{~km}$ from the mainland) and its high levels of federal protection (CONANP 2018) could protect these assemblages from overexploitation. This fact is supported by the results of the $\Delta^{+}$funnel plot, where the observed values for the oceanic group were close to the expected values, indicating that the fish assemblages in this region have suffered less alterations than those around the continental group (Clarke and Warwick 1998).

This type of study, in which the assemblages of fish in mesophotic depths are described quantitatively and qualitatively, may have relevant implications for management strategies, because some commercially important species could nichos funcionales está siendo cubierta en arrecifes rocosos del conjunto oceánico (Mouillot et al. 2014). Las diferencias entre ambos hábitats también fueron observadas al graficar el volumen funcional total cubierto por cada ensamblaje (Fig. 3), donde el arrecife rocoso del conjunto oceánico abarcó un $76 \%$ del total regional, en comparación con el $44 \%$ ocupado por el ensamblaje de zonas arenosas.

El mayor volumen funcional observado en los hábitats rocosos circundando al conjunto oceánico se puede asociar con la alta frecuencia de ocurrencia de elasmobranquios y especies transpacíficas en los arrecifes rocosos del archipiélago de Revillagigedo (23\%; Tabla S2). Las características funcionales extremas de los tiburones en relación con las de la demás ictiofauna pueden contribuir a aumentar la heterogeneidad funcional en un ensamblaje (Clarke y Warwick 1998, Rogers et al. 1999). Además de elasmobranquios, la fauna residente de estos arrecifes rocosos en islas oceánicas se ve enriquecida por gran variedad de especies transpacíficas (Robertson y Cramer 2009), que en su mayoría son bentopelágicas. Estas especies frecuentemente presentan grandes tallas, alta movilidad y amplia distribución, lo cual puede incrementar la heterogeneidad funcional, y por ende el volumen funcional y riqueza funcional total, de un ensamblaje. Este patrón ya se ha observado para otras islas oceánicas del Pacífico Tropical Oriental (Malpelo; Quimbayo et al. 2016). Cabe mencionar que algunas de estas especies con atributos extremos que presentaron altas frecuencias de ocurrencia ( $>23 \%$; Tabla S2), como Caranx lugubris y Seriola rivoliana, son consideradas especies de importancia comercial en México (DOF 2018).

De acuerdo con Pauly y Palomares (2005), la explotación pesquera tiende a remover primero especies de gran tamaño y alto nivel trófico por su gran valor comercial, por lo que la alta frecuencia de ocurrencia de tiburones y especies comerciales de peces óseos en arrecifes rocosos del conjunto oceánico podría asociarse a una menor presión pesquera derivada de la lejanía del archipiélago de Revillagigedo con respecto al continente $(>700 \mathrm{~km})$, así como a la restricción absoluta a actividades extractivas (CONANP 2018). Este hecho se apoya con los resultados de la gráfica de embudo de $\Delta^{+}$(Fig. S1), donde el conjunto oceánico mostró valores observados similares a los esperados, lo que indica que los ensamblajes de peces de este conjunto han sufrido menores alteraciones que los del conjunto continental (Clarke y Warwick 1998).

Es importante mencionar que este tipo de estudio, en donde se describe cuantitativa y cualitativamente a los ensamblajes de peces en profundidades mesofóticas, puede tener implicaciones relevantes para las estrategias de manejo, porque algunas especies de importancia comercial podrían encontrar refugio de la explotación pesquera en aguas más profundas. Sin embargo, la idea de que los arrecifes mesofóticos funcionan como refugios de especies comerciales aún no puede ser comprobada para la costa mexicana del Pacífico, debido a la falta de datos de abundancia y tallas de peces, así como de muestreos de estratos someros y 
find refuge from fishing in deeper waters. However, the idea that mesophotic reefs function as refuges for commercial species cannot yet be verified for the Pacific coast of Mexico, due to the lack of data on abundance and fish sizes and of samples of shallow and deep strata taken with the same technique (video-transects with a remotely operated vehicle). According to theory, the value of NT should increase with respect to depth, as it is driven by a greater abundance of high trophic level species (commercially important) that seek refuge in these strata (Loya et al. 2016) and by a decrease in herbivores $(\mathrm{NT}=2)$ due to the lack of seaweed coverage (reduced light limits primary production; Asher et al. 2017). This pattern was not observed for the fish assemblages in the mesophotic zone, which presented an average NT $(3.81 \pm 0.15$; Table S4) similar to that reported for fish in shallow reefs at Revillagigedo $(\mathrm{NT}=3.5)$ in the study by Fourriére et al. (2019).

Considering that the present work is a pioneer in the analysis of fish diversity in mesophotic reefs of the Pacific coast of Mexico, our results cannot be directly compared with most of the studies carried out in shallow depths $(<30 \mathrm{~m})$ of the Gulf of California (Aguilar -Medrano and Calderón-Aguilera 2015, Ramírez-Ortiz et al. 2017, Olivier et al. 2018) and the Revillagigedo Archipelago (Ramírez-Ortiz et al. 2017, Fourriére et al. 2019). However, it is necessary to highlight that, contrary to the homogeneity that we observed in the mesophotic zone, these regional studies have reported significant differences at shallow depths, including greater functional richness in Cortés province compared to the Mexican province (Aguilar-Medrano and Calderón-Aguilera 2015), and the Oceanic Islands province (Ramírez-Ortiz et al. 2017). In addition, these differences were also reported for the continental group, where Espíritu Santo and Cerralvo are even considered a biodiversity "hotspot" based on shallow fish, compared to the north and south of the Gulf of California (Olivier et al. 2018). Considering this, it will be necessary to carry out censuses with the same sampling method simultaneously in shallow and mesophotic reefs to try to determine if the heterogeneity between biogeographic provinces only occurs in the shallow strata.

Despite the fact that this study was based on a lower sampling effort $(13 \mathrm{~h})$ than comparable analyses of assemblages in the mesophotic zone of other regions such as the Gulf of Mexico (>20 h; Bryan et al. 2012, Streich et al. 2017), the accumulation curves indicated that the sample size was adequate to represent the fish assemblages of both island groups. In a complementary manner, this analysis and the study of Hollarsmith et al. (2020) constitute a qualitative and quantitative description of the mesophotic zone in Pacific waters off Mexico, an oceanographically complex and ecologically important region.

In conclusion, the diversity of fish in the mesophotic zone in the province of Cortés and the Oceanic Islands province were practically homogeneous, which is contrary to what was reported for shallow reef ichthyofauna. In contrast, habitat profundos tomados con la misma técnica (video-transectos con el vehículo operado remotamente). De acuerdo con la teoría, el valor de NT aumenta con respecto a la profundidad, lo que se asocia con una mayor abundancia de especies comerciales de altos niveles tróficos que buscan refugio en estos estratos (Loya et al. 2016), así como a la disminución de herbívoros $(\mathrm{NT}=2)$ en la zona mesofótica debido a la falta de alimento vegetal (poca cantidad de luz limita la fotosíntesis; Asher et al. 2017). Este patrón no se observó en los ensamblajes de peces de la zona mesofótica, que presentaron un NT promedio (3.81 \pm 0.15 ; Tabla S4) similar al reportado para peces de arrecifes someros de Revillagigedo $(\mathrm{NT}=3.5)$ en el estudio de Fourriére et al. (2019).

Dado que el presente trabajo es pionero en el análisis de diversidad de peces en arrecifes mesofóticos de la costa mexicana del Pacífico, nuestros resultados no pueden compararse de manera directa con la mayoría de los estudios realizados en estratos someros $(<30 \mathrm{~m})$ del golfo de California (Aguilar-Medrano y Calderón-Aguilera 2015, RamírezOrtiz et al. 2017, Olivier et al. 2018) y el archipiélago de Revillagigedo (Ramírez-Ortiz et al. 2017, Fourriére et al. 2019). Sin embargo, es necesario resaltar que, contrario a la homogeneidad que observamos en la zona mesofótica, estos estudios regionales han reportado diferencias significativas para zonas someras, como una mayor riqueza de grupos funcionales en sitios de la provincia de Cortés en comparación con la provincia Mexicana (Aguilar-Medrano y Calderón-Aguilera 2015), y la provincia de Islas Oceánicas (Ramírez-Ortiz et al. 2017). Además, estas diferencias también fueron reportadas para el conjunto continental, donde Espíritu Santo y Cerralvo incluso son consideradas un punto caliente de biodiversidad (hotspot), en comparación con el norte y el sur del golfo de California (Olivier et al. 2018). Con base en ello, es necesario realizar censos con el mismo método de muestreo de manera simultánea en arrecifes someros y mesofóticos para tratar de determinar si la homogeneidad entre provincias biogeográficas solo se presenta en estratos profundos.

A pesar de que en nuestro trabajo se llevó a cabo un menor esfuerzo de muestreo $(13 \mathrm{~h})$ en comparación con análisis de arrecifes mesofóticos de regiones como el golfo de México (>20 h; Bryan et al. 2012, Streich et al. 2017), las curvas de acumulación indicaron que el tamaño de muestra fue adecuado para representar los ensamblajes de peces de ambos conjuntos insulares (Fig. 2). De manera complementaria, este análisis y el de Hollarsmith et al. (2020) constituyen una primera aproximación a la descripción cualitativa y cuantitativa de una región oceanográficamente compleja y ecológicamente importante, como lo es la zona mesofótica a lo largo de la costa mexicana del Pacífico.

En conclusión, la diversidad de peces de la zona mesofótica en la provincia de Cortés y la provincia de Islas Oceánicas fue prácticamente homogénea, lo que resulta contrario a lo reportado para la ictiofauna de arrecifes someros. En contraste, el factor hábitat presentó un efecto en los índices tradicionales $\left(\mathrm{S}, \Delta^{+}\right.$y $\left.\mathrm{NT}\right)$, con valores más altos para los 
type influenced the traditional indices $\left(\mathrm{S}, \Delta^{+}\right.$, and NT), with higher values found for fish assemblages in rocky reef habitats (more complex) compared to sandy habitats, while the functional indices only differed among rock and sand habitats in the oceanic group. This was driven by numerous observations of sharks and transpacific fish in Revillagigedo, which resulted in greater functional heterogeneity among these assemblages. Altogether, high values of functional diversity and taxonomic distinctness observed in the oceanic group could indicate that the mesophotic fish assemblages of the oceanic region are in a better conservation status than those closer to the continent, but further exploration is required to observe if this pattern holds through time and to determine if these ecosystems serve as a refuge for commercial species in the face of the increasing anthropogenic threats to shallow reefs.

\section{ACKNOWLEDGMENTS}

Funds for the study were provided by the National Geographic Society (USA, Research and Exploration Grant CP-095ER-17), University of California Institute for Mexico and the United States (UC-MEXUS) Small Grant Program, The Explorer's Club Exploration Fund, American Philosophical Society Lewis and Clark Fund for Exploration and Field Research, NSF Graduate Research Fellowship Program (\#1650042 to JAH), and the Consejo Nacional de Ciencia y Tecnología (Mexico) doctoral scholarship (\#266599 to GRO). We thank the Universidad Autónoma de Baja California Sur, Centro de Investigaciones Biológicas del Noroeste (Eduardo Balart), Proazul Terrestre, Cortez Expeditions, and Sea Shepherd Conservation Society for the support with field trips that made this study possible. Thanks to the team that collaborated in technical support, field work, and fish identification: Blue Robotics, Kyle Neumann, Tallulah Winquist, Katie Dubois, Arturo Ayala-Bocos, Jeb Rabadan, Paul Preciado-González, Deneb Saldierna-Calapiz, Lazuli Piceno, Alexia Uribe, Jenny Rodríguez, and the crew of the M/V Sharpie. Finally, we thank Gabriel Ng and Helen Yan for their advice on the statistical analysis, Christian Cortés, and the 2 reviewers who helped improve this manuscript. The authors declare that they do not have conflicts of interest in relation to this article.

\section{REFERENCES}

Aburto-Oropeza O, Balart EF. 2001. Community structure of reef fish in several habitats of a rocky reef in the Gulf of California. Mar Ecol. 22(4):283-305. https://doi.org/10.1046/j.1439-0485.2001.01747.x

Aguilar-Medrano R, Calderon-Aguilera LE. 2015. Redundancy and diversity of functional reef fish groups of the Mexican Eastern Pacific. Mar Ecol. 37(1):119-133. https://doi.org/10.1111/maec.12253

Asher J, Williams ID, Harvey ES. 2017. Mesophotic depth gradients impact reef fish assemblage composition and functional group partitioning in the main Hawaiian islands. Front Mar Sci. 4:1-8. https://doi.org/10.3389/fmars.2017.00098 ensamblajes de peces en arrecifes rocosos (más complejos) en comparación con zonas arenosas. Sin embargo, los índices funcionales solo difirieron entre arrecifes rocosos y zonas arenosas en las islas oceánicas. Esto se asocia con la mayor frecuencia de ocurrencia de elasmobranquios e ictiofauna transpacífica en Revillagigedo, lo que resultó en una mayor heterogeneidad funcional entre estos ensamblajes. En conjunto, los altos valores de diversidad funcional y diferenciación taxonómica podrían indicar que los ensamblajes de peces mesofóticos del conjunto oceánico se encuentran en un mejor estado de conservación que los del conjunto continental, pero se requiere mayor exploración para observar si esta característica perdura a través del tiempo, así como para determinar si estos ecosistemas representan un refugio para especies comerciales ante el creciente impacto de amenazas en arrecifes someros.

\section{Agradecimientos}

Los fondos para la realización del estudio fueron proporcionados por National Geographic Society (EUA, Research and Exploration Grant CP-095ER-17), University of California Institute for Mexico and the United States (UC-MEXUS) Small Grant Program, The Explorer's Club Exploration Fund, American Philosophical Society Lewis and Clark Fund for Exploration and Field Research, NSF Graduate Research Fellowship Program (clave \#1650042 a JAH), así como la beca del Consejo Nacional de Ciencia y Tecnología (México) de doctorado (clave \#266599 a GRO). Agradecemos a la Universidad Autónoma de Baja California Sur, el Centro de Investigaciones Biológicas del Noroeste (Eduardo Balart), Proazul Terrestre, Cortez Expeditions y Sea Shepherd Conservation Society su apoyo con las salidas de campo que hicieron posible este estudio. Gracias al equipo que colaboró con apoyo técnico, trabajo de campo e identificación de peces: Blue Robotics, Kyle Neumann, Tallulah Winquist, Katie Dubois, Arturo Ayala-Bocos, Jeb Rabadan, Paul Preciado-González, Deneb Saldierna-Calapiz, Lazuli Piceno, Alexia Uribe, Jenny Rodríguez y equipo de B/M Sharpie. Finalmente, agradecemos a Gabriel Ng y Helen Yan su asesoría en el análisis estadístico, a Christian Cortés y a los 2 revisores que ayudaron a mejorar este manuscrito. Los autores declaran no tener conflictos de interés, en relación a este artículo.

Bryan DR, Kilfoyle K, Gilmore RG Jr, Spieler RE. 2012. Characterization of the mesophotic reef fish community in south Florida, USA. J Appl Icthyol. 29(1):108-117. https://doi.org/10.1111/j.1439-0426.2012.02055.x

Bürkner PC. 2018. Advanced Bayesian multilevel modeling with the R package brms. The R Journal. 10(1):395-411. https://doi.org/10.32614/RJ-2018-017

Castro R, Durazo R, Mascarenhas A, Collins CA, Trasviña A. 2006. Thermohaline variability and geostrophic circulation in the southern portion of the Gulf of California. Deep-Sea Res PT I. 53(1):188-200.

https://doi.org/10.1016/j.dsr.2005.09.010 
Clarke KR, Warwick RM. 1998. A taxonomic distinctness index and its statistical properties. J Appl Ecol. 35(4):523-531. https://doi.org/10.1046/j.1365-2664.1998.3540523.x

[CONANP] Comisión Nacional de Áreas Naturales Protegidas. 2015 Ene 19. Programa de Manejo Parque Nacional Exclusivamente la Zona Marina del Archipiélago de Espíritu Santo [National Park Management Program Exclusively the Marine Zone of the Espiritu Santo Archipelago]. Mexico City: Secretaría de Medio Ambiente y Recursos Naturales.

[CONANP] Comisión Nacional de Áreas Naturales Protegidas. 2018 Nov 30. Programa de Manejo Parque Nacional Revillagigedo [Revillagigedo National Park Management Program]. Mexico City: Secretaría de Medio Ambiente y Recursos Naturales.

Cornwell WK, Schwilk DW, Ackerly DD. 2006. A trait-based test for habitat filtering: Convex hull volume. Ecology. 87(6):14651471. https://doi.org/10.1890/0012-9658(2006)87[1465:ATTFHF]2.0.CO;2

Costello MJ, Tsai P, Wong PS, Cheung AKL, Basher Z, Chaudhary C. 2017. Marine biogeographic realms and species endemicity. Nat Commun. 8:1-10. https://doi.org/10.1038/s41467-017-01121-2

[DOF] Diario Oficial de la Federación. 2018 Jun 11. Carta Nacional Pesquera [National Fishing Charter]. Mexico City: Secretaría de Gobernación.

Dustan P, Doherty O, Pardede S. 2013. Digital reef rugosity estimates coral reef habitat complexity. PLOS ONE. 8(2):1-10. https://doi.org/10.1371/journal.pone.0057386

Fourriére M, Reyes-Bonilla H, Galván-Villa CM, Ayala Bocos A, Rodríguez-Zaragoza FA. 2019. Reef fish structure assemblages in oceanic islands of the eastern tropical Pacific: Revillagigedo Archipelago and Clipperton atoll. Mar Ecol. 40(3):1-14. https://doi.org/10.1111/maec.12539

Francisco V, de la Cueva H. 2017. Nuevas perspectivas en la diversidad funcional de ambientes marinos. Lat Am J Aquat Res. 45(2):261-275. http://doi.org/10.3856/vol45-issue2-fulltext-3

Froese R, Pauly D. 2019. FishBase. World Wide Web electronic publication. Stockholm (Sweden): FishBase; accessed 2019 May 02. https://www.fishbase.org

Glynn PW, Manzello DP, Enochs IC. 2017. Coral Reefs of the Eastern Tropical Pacific: Persistence and Loss in a Dynamic Environment. Coral Reefs of the World, Vol. 8. Netherlands: Springer Nature. $657 \mathrm{p}$. https://doi.org/10.1007/978-94-017-7499-4

Gotelli NJ, Colwell RK. 2001. Quantifying biodiversity: procedures and pitfalls in the measurement and comparison of species richness. Ecol Lett. 4(4):379-391. https://doi.org/10.1046/j.1461-0248.2001.00230.x

Gower JC. 1971. A general coefficient of similarity and some of its properties. Biometrics. 27(4):857-871. https://doi.org/10.2307/2528823

Halpern BS, Frazier M, Afflerbach J, Lowndes JS, Micheli F, O’Hara C, Scarborough C, Selkoe KA. 2019. Recent pace of change in human impact on the world's ocean. Sci Rep. 9(1):1-8. https://oi.org/10.1038/s41598-019-47201-9

Hollarsmith JA, Ramírez-Ortiz G, Winquist T, Velasco-Lozano M, DuBouis K, Reyes-Bonilla H, Neumann KC, Grosholz ED. 2020. Habitats and fish communities at mesophotic depths in the Mexican Pacific. J Biogeogr. 47(7):1552-1563. https://doi.org/10.1111/jbi.13842

Kahng SE, Akkaynak D, Shlesinger T, Hochberg EJ, Wiedenmann J, Tamir R, Tchernov D. 2019. Light, temperature, photsynthesis, heterotrophy, and the lower depth limits of mesophotic coral ecosystems. In: Loya Y, Puglise KA, Bridge TCL (eds.), Mesophotic Coral Ecosystems. Coral Reefs of the World, Vol. 12. Gewerbestrasse (Switzerland): Springer International Publishing. p. 801-828.

https://doi.org/10.1007/978-3-319-92735-0

Kelley C, Moffitt RB, Smith J. 2006. Mega- to micro-scale classification and description of bottomfish essential fish habitat on four banks in the Northwestern Hawaiian Islands. Atoll Res Bull. 543(543):319-332.

Laliberté E, Legendre P, Shipley B. 2014. FD: Measuring functional diversity (FD) from multiple traits, and other tools for functional ecology. R package version 1.0-12

Lenth R. 2019. emmeans: Estimated Marginal Means, aka LeastSquares Means. R package version 1.4.1.

León-de la Luz JL, Rebman JP. 2002. The vascular flora of Cerralvo Island. In: Case TJ, Cody ML, Ezcurra E (eds.), A new islands biogeography of the Sea of Cortés. New York (NY): Oxford University Press. p. 154-180.

Loya Y, Eyal G, Treibitz T, Lesser MP, Apperldoorn R. 2016. Theme section on mesophotic coral ecosystems: advances in knowledge and future perspectives. Coral Reefs. 35:1-9. https://doi.org/10.1007/s00338-016-1410-7

Maire E, Grenouillet G, Brosse S, Villéger S. 2015. How many dimensions are needed to accurately assess functional diversity? A pragmatic approach for assessing the quality of functional spaces. Global Ecol Biogeogr. 24(6):728-740. https://doi.org/10.1111/geb.12299

Mason NWH, Mouillot D, Lee WG, Wilson JB. 2005. Functional richness, functional evenness and functional divergence: the primary components of functional diversity. Oikos. 111(1): $112-118$. https://doi.org/10.1111/j.0030-1299.2005.13886.x

Mouillot D, Villéger S, Parravicini D, Kulbicki M, Arias-González JE, Bender M, Chabanet P, Floeter SR, Friedlander A, Vigliola $\mathrm{L}$, et al. 2014. Functional over-redundancy and high functional vulnerability in global fish faunas on tropical reefs. P Natl Acad Sci USA-Biol. 111(38):13757-13762. https://doi.org/10.1073/pnas.1317625111

Oksanen J, Blanchet FG, Friendly M, Kindt R, Legendre P, McGlinn D, Minchin PR, O'Hara RB, Simpson GL, Solymos P, et al. 2019. vegan: Community Ecology Package. R package version 2.5-4.

Olivier D, Loiseau N, Petatán-Ramírez D, Trujillo-Millán O, Suárez-Castillo AN, Torre J, Munguia-Vega A, Reyes-Bonilla H. 2018. Functional-biogeography of the reef fishes of the islands of the Gulf of California: Integrating functional divergence into marine conservation. Global Ecol Conserv. $16: 1-15$. https://doi.org/10.1016/j.gecco.2018.e00506

Pauly D, Palomares ML. 2005. Fishing down marine food web: It is far more pervasive than we thought. Bull Mar Sci. 76(2):197-211.

Petchey OL, Evans KL, Fishburn IS, Gaston KJ. 2007. Low functional diversity and no redundancy in British avian assemblages. J Anim Ecol. 76(5):977-985. http://doi.org/10.1111/j.1365-2656.2007.01271.x

Pinheiro HT, Bernardi G, Simon T, Joyeaux JC, Macieira RM, Gasparini JL, Rocha C, Rocha LA. 2017. Island biogeography of marine organisms. Nature. 549:82-85. https://doi.org/10.1038/nature23680

Portela E, Beier E, Barton ED, Castro R, Godínez V, PalaciosHernández E, Fiedler PC, Sánchez-Velasco L, Trasviña A. 2016. Water masses and circulation in the Tropical Pacific off Central Mexico and surrounding areas. J Phys Oceanogr. 46(10):3069-3081.

https://doi.org/10.1175/JPO-D-16-0068.1 
Quimbayo JP, Mendes TC, Kulbicki M, Floeter SR, Zapata FA. 2016. Unusual reef fish biomass and functional richness at Malpelo, a remote island in the Tropical Eastern Pacific. Environ Biol Fish. 100(2):149-162. https://doi.org/10.1007/s10641-016-0557-y

R Core Team. 2019. R: A language and environment for statistical computing. Vienna (Austria): R Foundation for Statistical Computing; accessed 2019 Apr 26. http://www.R-project.org/.

Renka RJ, Gebhardt A, Eglen S, Zuyev S, White D. 2020. tripack: Triangulation of irregularly spaced data. $\mathrm{R}$ package version 1.3-9.1

Ramírez-Ortiz G, Calderón-Aguilar LE, Reyes-Bonilla H, AyalaBocos A, Hernández L, Rivera-Melo FF, López-Pérez A, Dominici-Arosamena A. 2017. Functional diversity of fish and invertebrates in coral and rocky reefs of the Eastern Tropical Pacific. Mar Ecol. 38(4):1-9. https://doi.org/10.1111/maec.12447

Robertson DR, Allen GR. 2015. Shorefishes of the Tropical Eastern Pacific: online information system. Version 2.0. Balboa (Panama): Smithsonian Tropical Research Institute; accessed 2019 May 02. https://biogeodb.stri.si.edu/sftep/en/pages

Robertson DR, Cramer KL. 2009. Shore fishes and biogeographic subdivisions of the Tropical Eastern Pacific. Mar Ecol Prog Ser. 380:1-17. https://doi.org/10.3354/meps07925

Rogers SI, Clarke KR, Reynolds JD. 1999. The taxonomic distinctness of coastal bottom-dwelling fish communities of the
North-east Atlantic. J Anim Ecol. 68(4):769-782. https://doi.org/10.1046/j.1365-2656.1999.00327.x

Roussel JR, Barber CB, Habel K, Grasman R, Gramacy RB, Mozharovskyi P, Sterratt DC. 2019. geometry: Mesh Generation and Surface Tessellation. R package version 0.4.4

Streich MK, Ajemian MJ, Wetz JJ, Stunz GW. 2017. A comparison of fish community structure at mesophotic artificial reefs and natural banks in the Western Gulf of Mexico. Mar Coast Fish. 9(1):170-189. https://doi.org/10.1080/19425120.2017.1282897

Sydeman WJ, Thompson SA, Santora JA, Koslow JA, Goericke R, Ohman MD. 2015. Climate-ecosystem change off southern California: Time-dependent seabird predator-prey numerical responses. Deep Sea Res. PT II. 112:158-170. https://doi.org/10.1016/j.dsr2.2014.03.008

Turner JA, Babcock RC, Hovey R, Kendrick GA. 2017. Deep thinking: a systematic review of mesophotic coral ecosystems. ICES J Mar Sci. 74(9):2309-2320. https://doi.org/10.1093/icesjms/fsx085

Villéger S, Mason NWH, Mouillot D. 2008. New multidimensional functional diversity indices for a multifaceted framework in functional ecology. Ecology. 89(8):2290-2301. https://doi.org/10.1890/07-1206.1

Villéger S, Ramos-Miranda J, Flores-Hernández D, Mouillot D. 2010. Contrasting changes in taxonomic vs. functional diversity of tropical fish communities after habitat degradation. Ecol Appl. 20(6):1512-1522. https://doi.org/10.1890/09-1310.1

Received February 2020, accepted October 2020. 


\section{SUPPLEMENTARY MATERIAL}

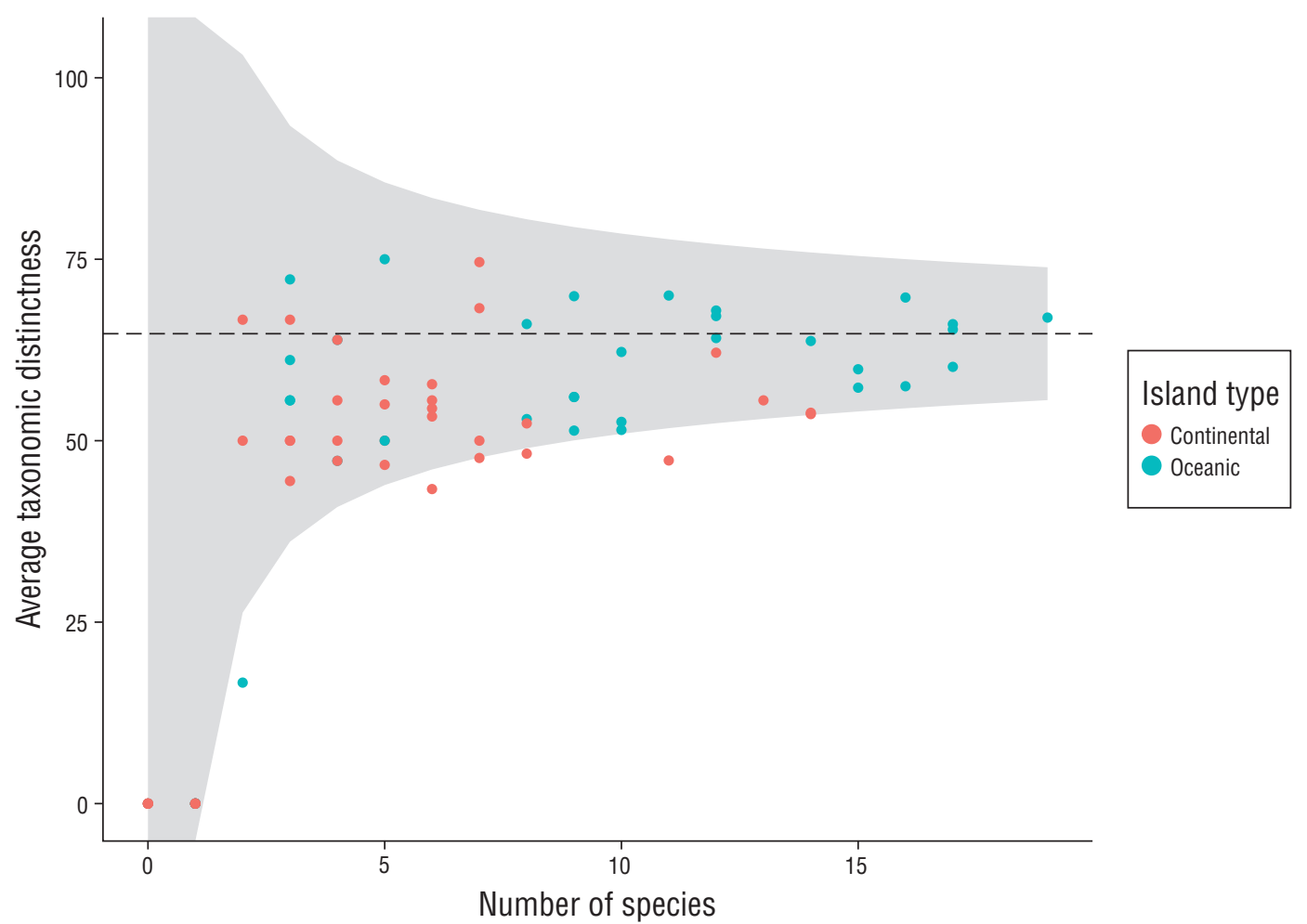

Figura S1. Average taxonomic distinctness funnel plot $\left(\Delta^{+}\right)$for each island group (continental and oceanic). The outermost lines show the upper and lower limits, and the dotted line shows the expected value of $\Delta^{+}$for each video-transect.

Figura S1. Gráfica de embudo para la diferenciación taxonómica promedio $\left(\Delta^{+}\right)$de acuerdo con el conjunto insular (continental y oceánico). Las líneas externas muestran el límite superior e inferior y la línea punteada indica el valor esperado de $\Delta^{+}$para cada video-transecto. 
Table S1. Biodiversity indices estimated in the present study with their respective formulas and components.

Tabla S1. Índices de diversidad calculados en el presente análisis con sus respectivas fórmulas y componentes.

\begin{tabular}{|c|c|c|}
\hline Metric & Formula & Components \\
\hline Average taxonomic distinctness $\left(\Delta^{+}\right)$ & $\Delta^{+}=\frac{\left[\sum \sum_{i<j} \omega_{i j}\right]}{\left[\frac{s(s-1)}{2}\right]}$ & $\begin{array}{l}\Sigma \Sigma_{i<j} \text { is double summation of } \\
\text { range } i \text { to } j \text { over } s \text { species. } \\
\omega_{j i} \text { s distinctness weight } \\
\text { (linked to hierarchical clas- } \\
\text { sification between species } i \\
\text { and } j \text { ). } \\
s \text { is the number of species } \\
\text { present per video-transect }\end{array}$ \\
\hline Trophic level (NT) & $N T_{j}=\frac{\sum_{i j} N T_{j} Y_{i j}}{\Sigma Y_{i j}}$ & $\begin{array}{l}N T_{j} \text { is the trophic level of } \\
\text { species } j \text {. } \\
Y_{i j} \text { is the number of species } i \\
\text { per video-transect. }\end{array}$ \\
\hline Functional richness (FRic) & $F R_{i c}=\frac{S F_{i c}}{R_{i}}$ & $\begin{array}{l}F R_{i c} \text { is the functional richness } \\
\text { of functional character } i \text { per } \\
\text { video-transect } c \text {. } \\
S F_{i c} \text { is the niche space filled } \\
\text { by the species within a vid- } \\
\text { eo-transect. } \\
R_{i} \text { is the absolute range of the } \\
\text { character. } \\
\text { This formula is used to es- } \\
\text { timate the value of a single } \\
\text { functional trait; therefore, it } \\
\text { changes depending on the } \\
\text { number of traits employed in } \\
\text { the study (Mason et al. 2005, } \\
\text { Francisco and de la Cueva } \\
2017 \text { ). }\end{array}$ \\
\hline
\end{tabular}


Tabla S2. Frequency of occurrence (percentage) of species per island group and habitat type, including the respective trophic level and functional entity. CRRH, continental rocky reef habitat; $\mathrm{CSH}$, continental sandy habitat; ORRH, oceanic rocky reef habitat; OSH, oceanic sandy habitat.

Tabla S2. Frecuencia de ocurrencia (porcentaje) de especies por conjunto insular y tipo de hábitat, incluido su nivel trófico y entidad funcional. CRRH, hábitat continental de arrecifes rocosos; CSH, hábitat arenoso continental; ORRH, hábitat de arrecifes rocosos oceánicos; OSH, hábitat arenoso oceánico.

\begin{tabular}{|c|c|c|c|c|c|c|}
\hline Species & $\begin{array}{c}\text { CRRH } \\
\text { ocurrence } \\
(\%)\end{array}$ & $\begin{array}{c}\mathrm{CSH} \\
\text { ocurrence } \\
(\%)\end{array}$ & $\begin{array}{c}\text { ORRH } \\
\text { ocurrence } \\
(\%)\end{array}$ & $\begin{array}{c}\text { OSH } \\
\text { ocurrence } \\
(\%)\end{array}$ & Trophic level & $\begin{array}{c}\text { Functional } \\
\text { entity }\end{array}$ \\
\hline Class: Actinopterygii & 96 & 94.00 & 77.00 & 86.00 & & \\
\hline Acanthurus nigricans & 0 & 0 & 6.67 & 0 & 2.00 & $32 \mathrm{~A} 11 \mathrm{~A}$ \\
\hline Acanthurus xanthopterus & 8 & 0 & 3.33 & 0 & 2.90 & $53 \mathrm{~A} 11 \mathrm{~A}$ \\
\hline Anisotremus interruptus & 20 & 6.25 & 26.67 & 42.85 & 3.50 & $53 \mathrm{~B} 12 \mathrm{C}$ \\
\hline Arothron meleagris & 0 & 0 & 3.33 & 0 & 3.40 & $42 \mathrm{~A} 11 \mathrm{~B}$ \\
\hline Aulostomus chinensis & 0 & 0 & 10.00 & 28.57 & 3.90 & $52 \mathrm{~A} 11 \mathrm{E}$ \\
\hline Balistes polylepis & 12 & 18.75 & 10.00 & 28.57 & 3.30 & $53 \mathrm{~A} 11 \mathrm{C}$ \\
\hline Bodianus diplotaenia & 16 & 12.50 & 53.33 & 42.85 & 3.40 & $53 \mathrm{~A} 11 \mathrm{C}$ \\
\hline Cantherhines dumerilii & 0 & 0 & 10.00 & 0 & 3.10 & $43 \mathrm{~A} 11 \mathrm{~F}$ \\
\hline Caranx caballus & 4 & 6.25 & 0 & 0 & 4.10 & $54 \mathrm{~A} 42 \mathrm{E}$ \\
\hline Caranx lugubris & 0 & 0 & 53.33 & 71.42 & 4.50 & 64B42E \\
\hline Caranx melampygus & 0 & 0 & 30.00 & 14.28 & 4.50 & $64 \mathrm{~A} 32 \mathrm{E}$ \\
\hline Caranx sp. & 0 & 0 & 3.33 & 0 & 4.10 & $53 \mathrm{~A} 43 \mathrm{E}$ \\
\hline Cephalopholis panamensis & 4 & 0 & 6.67 & 0 & 4.20 & 42A11E \\
\hline Chaetodon humeralis & 8 & 0 & 0 & 0 & 2.70 & $32 \mathrm{~A} 31 \mathrm{~F}$ \\
\hline Chilomycterus reticulatus & 4 & 0 & 3.33 & 14.28 & 3.50 & $52 \mathrm{~A} 12 \mathrm{~B}$ \\
\hline Chromis alta & 4 & 6.25 & 33.33 & 42.85 & 3.40 & $22 \mathrm{~A} 12 \mathrm{D}$ \\
\hline Chromis limbaughi & 36 & 18.75 & 0 & 0 & 3.40 & $21 \mathrm{~A} 31 \mathrm{D}$ \\
\hline Dermatolepis dermatolepis & 0 & 0 & 20.00 & 28.57 & 4.50 & $63 \mathrm{~A} 11 \mathrm{E}$ \\
\hline Diodon holocanthus & 16 & 6.25 & 36.67 & 14.28 & 3.30 & 42B11C \\
\hline Diodon hystrix & 4 & 0 & 0 & 0 & 3.70 & $42 \mathrm{~B} 11 \mathrm{C}$ \\
\hline Elagatis bipinnulata & 0 & 0 & 3.33 & 0 & 4.30 & $64 \mathrm{~A} 33 \mathrm{E}$ \\
\hline Epinephelus cifuentesi & 0 & 0 & 23.33 & 14.28 & 3.00 & $64 \mathrm{~A} 11 \mathrm{E}$ \\
\hline Epinephelus clippertonensis & 0 & 0 & 23.33 & 0 & 3.90 & $52 \mathrm{~B} 11 \mathrm{E}$ \\
\hline Epinephelus labriformis & 12 & 6.25 & 33.33 & 28.57 & 4.00 & $52 \mathrm{~B} 11 \mathrm{E}$ \\
\hline Fistularia commersonii & 4 & 6.25 & 10.00 & 0 & 4.30 & $63 \mathrm{~A} 12 \mathrm{E}$ \\
\hline Forcipiger flavissimus & 0 & 0 & 23.33 & 0 & 3.10 & $32 \mathrm{~A} 32 \mathrm{~B}$ \\
\hline Gymnothorax castaneus & 0 & 0 & 3.33 & 0 & 4.00 & $61 \mathrm{~B} 11 \mathrm{E}$ \\
\hline Haemulon sexfasciatum & 16 & 6.25 & 0 & 0 & 4.20 & $53 \mathrm{~B} 31 \mathrm{E}$ \\
\hline Haemulon sp. & 0 & 0 & 3.33 & 0 & 4.20 & $53 \mathrm{~B} 31 \mathrm{E}$ \\
\hline Halichoeres dispilus & 12 & 0 & 0 & 0 & 3.90 & $32 \mathrm{~A} 11 \mathrm{C}$ \\
\hline Halichoeres sp. & 16 & 6.25 & 6.67 & 0 & 3.50 & $32 \mathrm{~A} 11 \mathrm{C}$ \\
\hline Heteroconger sp. & 4 & 18.75 & 0 & 0 & 3.40 & 51A11D \\
\hline Heteropriacanthus cruentatus & 0 & 0 & 20.00 & 0 & 3.60 & $52 \mathrm{~B} 12 \mathrm{C}$ \\
\hline Holacanthus clarionensis & 0 & 0 & 43.33 & 42.85 & 2.60 & $22 \mathrm{~A} 32 \mathrm{~B}$ \\
\hline Holacanthus passer & 40 & 18.75 & 0 & 0 & 2.60 & $42 \mathrm{~A} 32 \mathrm{~B}$ \\
\hline
\end{tabular}


Ciencias Marinas, Vol. 46, No. 4, 2020

Table S2 (Cont.)

\begin{tabular}{|c|c|c|c|c|c|c|}
\hline Species & $\begin{array}{c}\text { CRRH } \\
\text { ocurrence } \\
(\%) \\
\end{array}$ & $\begin{array}{c}\mathrm{CSH} \\
\text { ocurrence } \\
(\%) \\
\end{array}$ & $\begin{array}{c}\text { ORRH } \\
\text { ocurrence } \\
(\%)\end{array}$ & $\begin{array}{c}\text { OSH } \\
\text { ocurrence } \\
(\%)\end{array}$ & Trophic level & $\begin{array}{c}\text { Functional } \\
\text { entity }\end{array}$ \\
\hline Johnrandallia nigrirostris & 4 & 12.50 & 0 & 0 & 3.00 & $32 \mathrm{~A} 32 \mathrm{~F}$ \\
\hline Liopropoma fasciatum & 44 & 12.50 & 0 & 0 & 3.60 & $33 \mathrm{~A} 11 \mathrm{C}$ \\
\hline Lutjanus argentiventris & 28 & 6.25 & 3.33 & 0 & 4.00 & $53 \mathrm{~B} 41 \mathrm{E}$ \\
\hline Lutjanus guttatus & 0 & 12.50 & 0 & 0 & 3.90 & $53 \mathrm{~B} 12 \mathrm{C}$ \\
\hline Lutjanus jordani & 28 & 18.75 & 0 & 0 & 4.50 & $53 \mathrm{~B} 41 \mathrm{E}$ \\
\hline Lutjanus novemfasciatus & 8 & 6.25 & 0 & 0 & 4.10 & 64B11E \\
\hline Lutjanus viridis & 0 & 0 & 13.33 & 0 & 4.20 & $33 \mathrm{~B} 32 \mathrm{E}$ \\
\hline Mulloidichthys dentatus & 8 & 0 & 0 & 0 & 3.70 & $43 \mathrm{~B} 31 \mathrm{C}$ \\
\hline Muraena argus & 4 & 12.50 & 0 & 0 & 4.00 & 61B11E \\
\hline Mycteroperca rosacea & 16 & 6.25 & 0 & 0 & 4.50 & $63 \mathrm{~B} 11 \mathrm{E}$ \\
\hline Ostracion meleagris & 4 & 0 & 0 & 0 & 2.70 & $32 \mathrm{~A} 11 \mathrm{~F}$ \\
\hline Paranthias colonus & 44 & 12.50 & 63.33 & 57.14 & 3.80 & $43 \mathrm{~A} 42 \mathrm{D}$ \\
\hline Prionurus laticlavius & 16 & 0 & 0 & 0 & 2.70 & $53 \mathrm{~A} 41 \mathrm{~A}$ \\
\hline Pristigenys serrula & 24 & 0 & 10.00 & 0 & 4.00 & $42 \mathrm{~B} 12 \mathrm{E}$ \\
\hline Prognathodes falcifer & 40 & 6.25 & 30.00 & 14.28 & 3.30 & $22 \mathrm{~A} 12 \mathrm{~B}$ \\
\hline Quassiremus evionthas & 0 & 0 & 3.33 & 14.28 & 3.80 & 51A11E \\
\hline Scarus ghobban & 8 & 0 & 0 & 0 & 2.00 & $63 \mathrm{~A} 11 \mathrm{~A}$ \\
\hline Scorpaena guttatta & 8 & 0 & 0 & 0 & 3.80 & 41B11E \\
\hline Scorpaena sp. & 0 & 0 & 6.67 & 28.57 & 3.69 & 41B11E \\
\hline Semicossyphus pulcher & 4 & 6.25 & 0 & 0 & 3.60 & $63 \mathrm{~A} 11 \mathrm{C}$ \\
\hline Seriola rivoliana & 8 & 12.50 & 23.33 & 85.71 & 4.50 & $64 \mathrm{~A} 32 \mathrm{E}$ \\
\hline Serranus psittacinus & 24 & 0 & 0 & 0 & 3.60 & $32 \mathrm{~A} 11 \mathrm{E}$ \\
\hline Serranus socorroensis & 0 & 0 & 3.33 & 14.28 & 3.30 & $22 \mathrm{~A} 11 \mathrm{E}$ \\
\hline Stegastes leucorus & 0 & 0 & 13.33 & 0 & 2.00 & $21 \mathrm{~A} 11 \mathrm{~A}$ \\
\hline Stegastes sp. & 4 & 0 & 3.33 & 0 & 2.25 & $21 \mathrm{~A} 11 \mathrm{~A}$ \\
\hline Sufflamen verres & 4 & 12.50 & 10.00 & 0 & 3.30 & $43 \mathrm{~A} 31 \mathrm{C}$ \\
\hline Synodus lacertinus & 16 & 12.50 & 0 & 0 & 4.20 & 31B11E \\
\hline Thalassoma lucasanum & 0 & 0 & 3.33 & 0 & 3.50 & $22 \mathrm{~A} 31 \mathrm{C}$ \\
\hline Xanthichthys mento & 0 & 0 & 53.33 & 71.42 & 4.00 & $33 \mathrm{~A} 12 \mathrm{D}$ \\
\hline Zanclus cornutus & 2.44 & 0 & 10.00 & 0 & 2.90 & $32 \mathrm{~A} 31 \mathrm{~B}$ \\
\hline Class: Elasmobranchii & 4.00 & 6.00 & 23.00 & 14.00 & & \\
\hline Carcharhinus albimarginatus & 0 & 0 & 40.00 & 14.28 & 4.20 & $64 \mathrm{~A} 12 \mathrm{E}$ \\
\hline Carcharhinus falciformis & 0 & 0 & 36.67 & 0 & 4.50 & $64 \mathrm{~A} 12 \mathrm{E}$ \\
\hline Carcharhinus galapagensis & 0 & 0 & 13.33 & 0 & 4.20 & $64 \mathrm{~A} 32 \mathrm{E}$ \\
\hline Hypanus longus & 0 & 0 & 3.33 & 0 & 3.50 & $61 \mathrm{~A} 11 \mathrm{~F}$ \\
\hline Triaenodon obesus & 0 & 0 & 23.33 & 14.28 & 4.20 & 64B12E \\
\hline Urobatis concentricus & 0 & 6.25 & 0 & 0 & 3.30 & $42 \mathrm{~A} 11 \mathrm{C}$ \\
\hline Urobatis sp. & 4 & 0 & 0 & 0 & 3.23 & $42 \mathrm{~A} 11 \mathrm{C}$ \\
\hline Urotrygon sp. & 4 & 0 & 0 & 0 & 3.63 & $42 \mathrm{~A} 11 \mathrm{~B}$ \\
\hline
\end{tabular}


Tabla S3. Results for the Bayesian generalized linear mixed models, including estimated value and credible interval (CI) at $95 \%$. Factors in bold indicate a significant effect (i.e., CI does not overlap zero).

Tabla S3. Resultados de los modelos generalizados mixtos bayesianos que incluyen el valor estimado y el intervalo creíble (CI) al 95\%. Los factores en negritas indican un efecto significativo (i.e., CI no se sobrepone al cero).

\begin{tabular}{|c|c|c|}
\hline & Estimate & $95 \% \mathrm{CI}$ \\
\hline \multicolumn{3}{|l|}{ Species richness } \\
\hline Intercept & 1.88 & 1.11 to 2.63 \\
\hline Island group: oceanic & 0.55 & -0.47 to 1.55 \\
\hline Habitat: sand & -1.18 & -1.87 to -0.56 \\
\hline Island group (oceanic) $\times$ habitat (sand) & -0.26 & -1.06 to 0.55 \\
\hline \multicolumn{3}{|l|}{ Average taxonomic distinctness } \\
\hline Intercept & 53.03 & 40.21 to 69.28 \\
\hline Island group: oceanic & 16.89 & -4.84 to 36.70 \\
\hline Habitat: sand & -30.67 & -50.45 to -11.11 \\
\hline Island group (oceanic) $\times$ habitat (sand) & -5.68 & -32.19 to 19.49 \\
\hline \multicolumn{3}{|l|}{ Trophic level } \\
\hline Intercept & 3.43 & 2.35 to 4.54 \\
\hline Island group: oceanic & 0.36 & -1.05 to 1.86 \\
\hline Habitat: sand & -1.02 & -1.87 to -0.13 \\
\hline Island group (oceanic) $\times$ habitat (sand) & 0.91 & -0.30 to 2.05 \\
\hline \multicolumn{3}{|l|}{ Functional richness } \\
\hline Intercept & 0.05 & -0.08 to 0.17 \\
\hline Island group: oceanic & 0.12 & -0.04 to 0.29 \\
\hline Habitat: sand & -0.03 & -0.09 to 0.03 \\
\hline Island group $($ oceanic) $\times$ habitat (sand) & -0.12 & -0.23 to -0.02 \\
\hline
\end{tabular}


Tabla S4. Average values (mean \pm standard error) for each diversity index estimated for each island group, island, and habitat type. S, species richness; $\Delta^{+}$, average taxonomic distinctness; NT, throphic level; FRic, average functional richness.

Tabla S4. Valores promedio por índice de diversidad (promedio \pm error estándar) calculados para cada conjunto insular, isla y tipo de hábitat. S, riqueza de especies; $\Delta^{+}$, diferenciación taxonómica promedio; NT, nivel trófico; FRic, riqueza funcional promedio.

\begin{tabular}{lcccc}
\hline & $\mathrm{S}$ & \multicolumn{1}{c}{$\Delta^{+}$} & $\mathrm{NT}$ & FRic \\
\hline Continental islands & $4.78 \pm 0.61$ & $44.34 \pm 4.48$ & $3.11 \pm 0.21$ & $0.05 \pm 0.01$ \\
Espíritu Santo & $4.68 \pm 0.84$ & $44.13 \pm 5.04$ & $3.01 \pm 0.24$ & $0.04 \pm 0.01$ \\
Cerralvo & $5.10 \pm 1.57$ & $44.98 \pm 10.16$ & $3.41 \pm 0.39$ & $0.10 \pm 0.05$ \\
Rocky reef habitat & $5.96 \pm 0.81$ & $52.55 \pm 4.35$ & $3.28 \pm 0.20$ & $0.07 \pm 0.02$ \\
Sandy habitat & $2.94 \pm 0.71$ & $31.51 \pm 8.47$ & $2.84 \pm 0.43$ & $0.02 \pm 0.01$ \\
& & & & \\
Oceanic islands & $8.43 \pm 0.94$ & $54.44 \pm 4.39$ & $3.81 \pm 0.15$ & $0.20 \pm 0.02$ \\
San Benedicto & $12.33 \pm 1.55$ & $68.56 \pm 2.29$ & $3.74 \pm 0.04$ & $0.22 \pm 0.04$ \\
Socorro & $15.67 \pm 2.40$ & $74.70 \pm 0.37$ & $3.74 \pm 0.05$ & $0.30 \pm 0.09$ \\
Clarión & $6.16 \pm 0.96$ & $46.92 \pm 5.90$ & $3.85 \pm 0.08$ & $0.17 \pm 0.03$ \\
Rocky reef habitat & $8.52 \pm 1.06$ & $54.53 \pm 4.85$ & $3.80 \pm 0.06$ & $0.21 \pm 0.03$ \\
Sandy habitat & $8.00 \pm 2.1$ & $53.92 \pm 11.28$ & $3.87 \pm 0.10$ & $0.20 \pm 0.05$ \\
& & & & \\
Habitat & & & $3.57 \pm 0.10$ & $0.15 \pm 0.02$ \\
Rocky reef & $7.38 \pm 0.71$ & $53.65 \pm 3.29$ & $3.12 \pm 0.33$ & $0.09 \pm 0.04$ \\
Sandy & $4.32 \pm 0.89$ & $37.62 \pm 7.09$ & & \\
\hline
\end{tabular}

